\title{
The Pennsylvanian Springhill Mines Formation: sedimentological framework of a portion of the Joggins Fossil Cliffs UNESCO World Heritage Site
}

\author{
Michael C. Rygel ${ }^{1^{*}}$, Erin P. Sheldon ${ }^{1}$, Matthew R. Stimson ${ }^{2}$, John H. Calder ${ }^{3}$, \\ Kyle T. AshleY ${ }^{1}$, AND JAmie L. SAlg ${ }^{1}$ \\ 1. Department of Geology, State University of New York, College at Potsdam, 44 Pierrepont Ave., \\ Potsdam, New York 13676, USA \\ 2. Department of Geology, Saint Mary's University, Halifax, Nova Scotia B3H 3C3, Canada \\ 3. Nova Scotia Department of Natural Resources, Halifax, Nova Scotia B3J 2T9, Canada \\ *Corresponding author $<$ rygelmc@potsdam.edu $>$
}

Received 22 October 2013 accepted 06 February 2014

\begin{abstract}
This is the first detailed study of the coastal exposure of the Springhill Mines Formation within the Joggins Fossil Cliffs World Heritage Site. A 16.9-m-thick interval of dark laminated mudrocks and sharpbased sandstones at the base of our section is reassigned to the top of the Joggins Formation. This interval records a rapid, presumably widespread flooding event and the temporary establishment of a marginalmarine to brackish bay. The overlying $697 \mathrm{~m}$ of strata represent deposition in poorly drained and well-drained environments, and are assigned to the Springhill Mines Formation. Strata reflecting poorly drained environments contain green and grey mudrocks, thin coals, sheet sandstones, and channel bodies interpreted to have been deposited in coastal swamps and low-lying parts of a floodplain. Intervals reflecting well-drained conditions contain reddish brown mudrocks, sheet sandstones, and channel bodies interpreted to have been deposited on a vegetated floodplain that was periodically exposed to oxidizing conditions. Strata reflecting poorly drained conditions are thick and abundant in the lower half of the formation and well-drained intervals become thick and more abundant in the upper half. The shift in facies abundance is accompanied by an interpreted evolution in fluvial style from predominantly anastomosed channels (below $376 \mathrm{~m}$ ) to sheet-like channel bodies (376$449 \mathrm{~m})$ and ultimately to predominantly meandering-channel bodies $(449-697 \mathrm{~m})$. The formation-scale changes in drainage conditions and fluvial style records decreased halokinetic subsidence and aggradation of the alluvial surface as sediments shed from the Caledonia Highlands prograded into this part of the basin.
\end{abstract}

\section{RÉSUMÉ}

Il sagit de la première étude détaillée sur l'exposition du littoral de la formation de Springhill Mines au sein $\mathrm{du}$ site du patrimoine mondial des falaises fossilifères de Joggins. Un intervalle de 16,9 $\mathrm{m}$ d'épaisseur de pélites feuilletées foncées et de grès à base nette situé au bas de la section a été rattaché au sommet de la formation de Joggins. Cet intervalle est le résultat d'une inondation rapide et probablement de grande envergure ainsi que de la formation temporaire d'un marginal marin dans une baie saumâtre. La couche sous jacente de $697 \mathrm{~m}$ de strate représente un dépôt dans des milieux mal drainés et bien drainés. Ces milieux se trouvent dans la formation de 
Springhill Mines. Les strates faisant état de milieux mal drainés contiennent des pélites vertes et grises, de minces couches de charbon, des couvertures de grès et des chenaux à géométrie planaire pouvant être interprétés comme des dépôts dans des marécages côtiers et les terres basses d'une plaine d'inondation. Les intervalles faisant état de bonnes conditions de drainage contiennent des pélites brun rouge, des couvertures de grès et des chenaux à géométrie planaire pouvant être interprétés comme des dépôts sur une plaine d'inondation végétalisée qui a été périodiquement exposée à des conditions oxydantes. Les strates faisant état de mauvaises conditions de drainage sont épaisses et abondantes dans la partie inférieure de la formation alors que les intervalles bien drainés deviennent épais et plus abondants dans la partie supérieure. Le changement dans l'abondance du faciès est accompagné par une évolution interprétée du style fluvial allant d'un faciès principalement composé de chenaux anastomosés (en dessous de $376 \mathrm{~m}$ ) à des chenaux à géométrie planaire ressemblant à des couvertures (de $376 \mathrm{~m}$ à $449 \mathrm{~m}$ ) et ultimement à des chenaux à géométrie planaire principalement sinueux (de $449 \mathrm{~m}$ à $697 \mathrm{~m}$ ). Les changements à l'échelle de la formation des conditions de drainage et du style fluvial font état d'une diminution de l'affaissement cinétique salifère et d'un alluvionnement de la surface alors que les sédiments provenant des hautes terres calédoniennes se sont accumulés dans cette partie du bassin.

[Traduit par la redaction]

\section{INTRODUCTION}

The Joggins Fossil Cliffs UNESCO World Heritage Site is a $14.7 \mathrm{~km}$ long coastal exposure that is widely regarded as the world's best example of coal-bearing Pennsylvanian rocks (Lyell 1871; Calder 1998; Calder 2012). This site was inscribed as a UNESCO World Heritage Site because it contains a remarkably complete in-situ record of terrestrial life preserved within a spectrum of depositional environments (Boon and Calder 2007). Aside from recent work on the underlying Little River and Joggins formations (Calder et al. 2005; Davies et al. 2005), much of the $4.5 \mathrm{~km}$ thickness of the Joggins section has not been described in detail since the pioneering work of William Logan (Rygel and Shipley, 2005). The lack of a basic sedimentological context for much of the section is a deficiency that prevents a fuller understanding of this iconic Pennsylvanian locality (Grey and Finkel 2011).

The 697-m-thick Springhill Mines Formation is one of the youngest formations within the formal boundaries of the World Heritage Site; the southern point of the designated cliff section being $\sim 90 \mathrm{~m}$ upsection from the contact between the Springhill Mines Formation and the overlying Ragged Reef Formation (Figs. 1, 2). The Springhill Mines Formation contains many of the features that make the Joggins Fossil Cliffs famous, including 29 thin coal seams, dozens of horizons with standing vegetation, and numerous alternations between wetland deposits and redbeds. Because this coastal exposure lacks coals of mineable thickness, it received less attention from early researchers than the Joggins Formation. In the absence of obvious marine influence and rhythmic sedimentation, this unit has largely been overlooked by later workers in favor of the underlying Joggins and Boss Point formations (Browne and Plint 1994; Davies and Gibling 2003; Gibling and Rygel 2008). Rapid halokinetic subsidence (Waldron and Rygel 2005; Waldron et al. 2013) during deposition of the Springhill Mines Formation contributed to the unusually complete preservation of forested overbank areas, even within redbed-dominated intervals. Unlike many of the underlying units, the coastal exposure of the Springhill Mines Formation does not exist in stratigraphic isolation; strata of this formation can be correlated inland to coalbearing intervals near Springhill, where coal beds up to 4.3 $\mathrm{m}$ thick alternate with 20 -m-thick multistorey sandstone bodies (Calder et al. 1991; Calder 1994). The combination of rapid, remarkably complete preservation and the potential for inland correlation makes the Springhill Mines Formation a promising target for studies of Pennsylvanian paleoecology and landscape dynamics outside of the coal swamps (sensu Falcon-Lang 1999; Falcon-Lang and Scott 2000; Falcon-Lang et al. 2010; Dimitrova et al. 2011).

This manuscript is the third in a series dedicated to providing detailed measured sections, maps, and a sedimentological framework for the formations within the World Heritage Site (see also Calder et al. 2005; Davies et al. 2005). We provide a detailed measured section of the coastal exposure in Appendix 3 and a simplified version of the measured section in Fig. 3. These portrayals of the stratigraphy are linked to a detailed map of the 3.1-km-long coastal exposure of the Springhill Mines Formation between the Joggins Fossil Centre and Ragged Reef Point (Fig. 2). The measured section, map, and descriptions contained herein are provided as a framework for future studies of this remarkable and understudied section.

\section{GEOLOGIC SETTING}

\section{Tectonics}

The Springhill Mines Formation (Pennsylvanian) was deposited in the western part of the Cumberland Basin, a $3600 \mathrm{~km}^{2}$ depocenter within the regional Maritimes Basin (Ryan and Boehner 1994; Gibling et al. 2008). Situated between the crystalline rocks of the Caledonia and Cobequid highlands, the margins of this fault-bounded depocenter are defined by the Harvey-Hopewell Fault to the west, the 


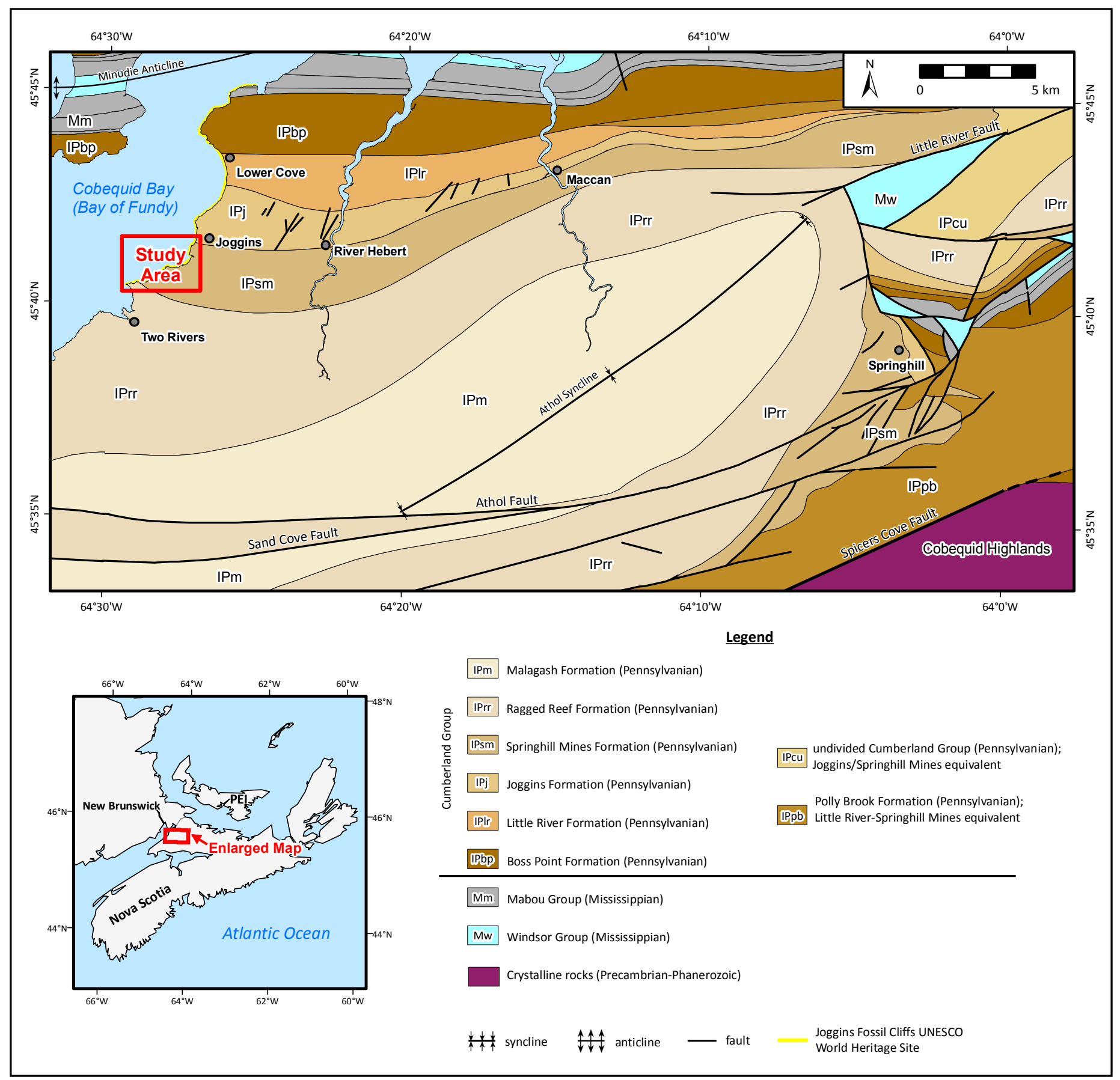

Figure 1. Geologic map of the western Cumberland Basin showing the study area along the coast, the distribution of the Springhill Mines Formation, and the extent of the Joggins Fossil Cliffs UNESCO World Heritage Site. A 1:10,000 scale map of the coastal section is provided in Fig. 2. Modified from Ryan et al. (1990 a, b), New Brunswick Department of Natural Resources and Energy (2000), and Keppie (2006). 


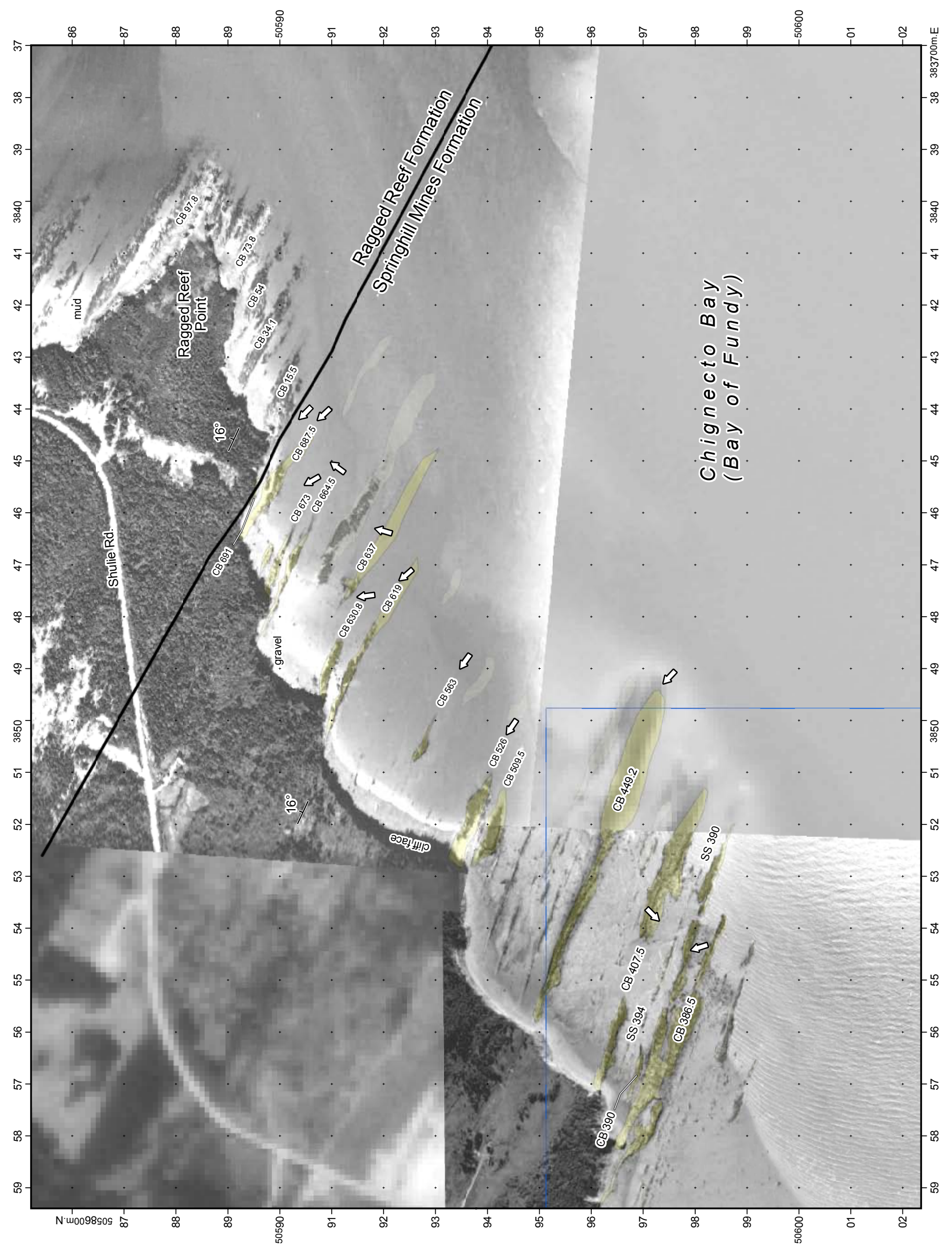




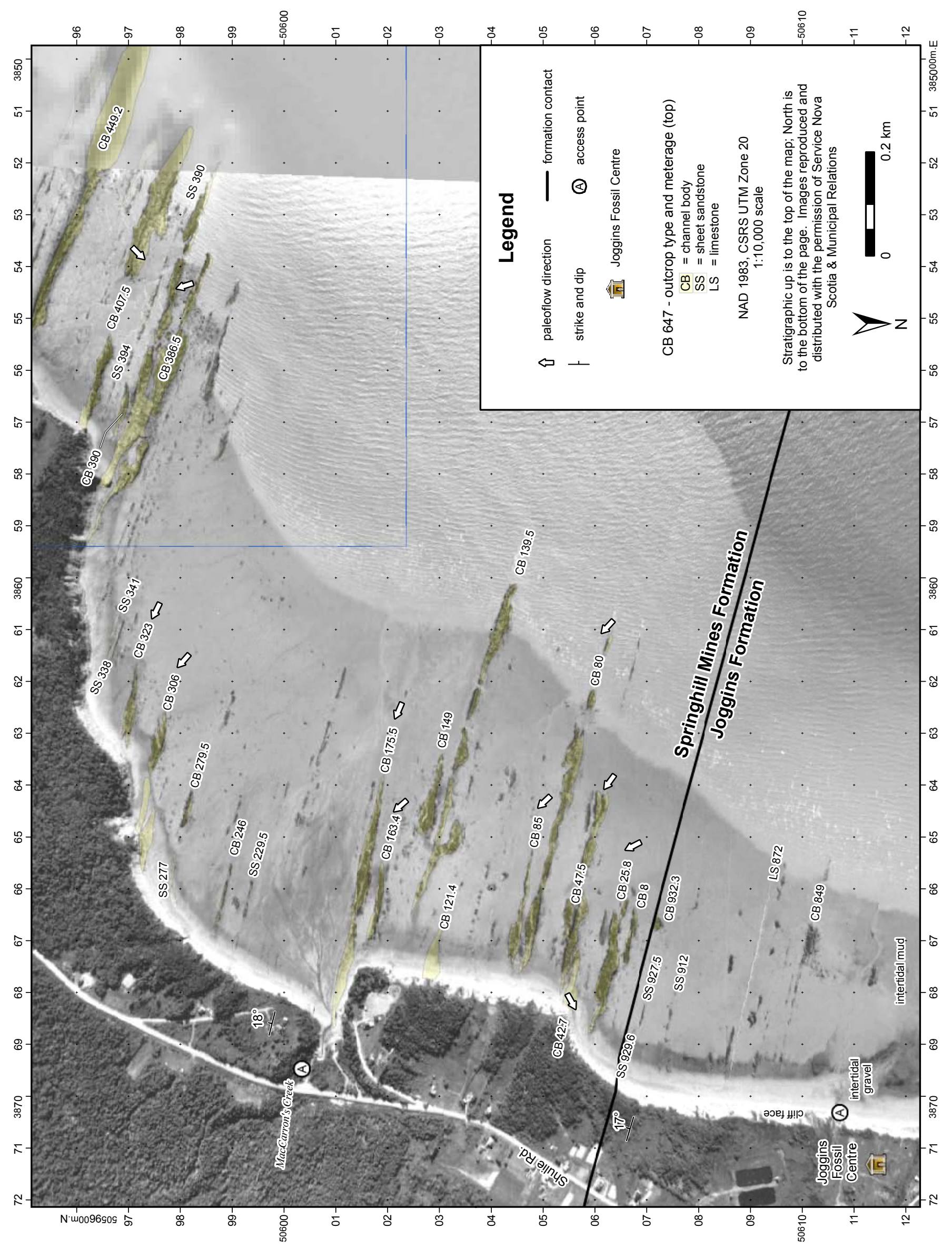


Figures 2a, 2b. (previous two pages) 1:10,000 scale map showing the coastal exposure of the Springhill Mines Formation. The background image is photomosaic constructed from airphotos showing the intertidal zone at low tide. Airphotos were georeferenced using satellite image 38435 from the NASA's Earth Observatory collection (http://earthobservatory.nasa. gov/IOTD/view.php?id=38435). Prominent outcrops in the intertidal zone are labeled with prefixes to indicate outcrop type and numbers to indicate stratigraphic position in the measured section. Blue lines are extent rectangles that show the area of overlap between the images. This map was produced by the authors and includes data that was reproduced with the permission of, and provided by, Service Nova Scotia and Municipal Relations (airphoto numbers 85314-2, 85323-105, 85323-104, and 95020-195). The incorporation of data sourced from Service Nova Scotia and Municipal Relations within this product shall not be construed as constituting an endorsement of our map by Service Nova Scotia and Municipal Relations.

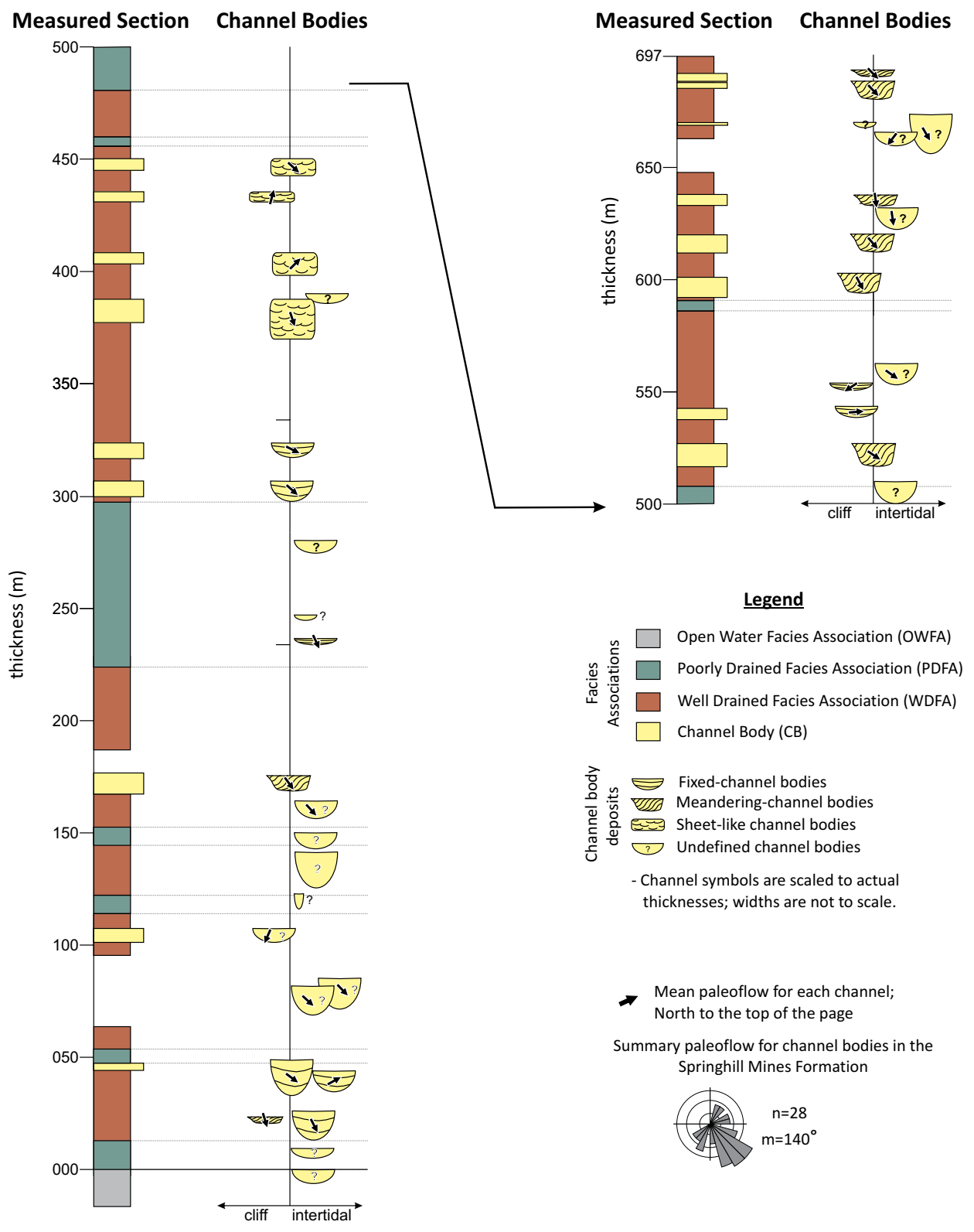

Figure 3. Summary section derived from Appendix 3 showing facies associations, major channel body types and locations, and paleoflow direction. 
Spicer's Cove Fault to the south, and the Wood CreekHastings Fault to the northeast (Browne and Plint 1994). The northeastern margin below the Gulf of St. Lawrence is poorly constrained; it may be locally defined by a basement horst along the Hastings Fault (Martel 1987). The bounding faults have a complex history (Webb 1963; Browne and Plint 1994) and are part of a regional network that facilitated about $250 \mathrm{~km}$ of dextral strike-slip motion in the Pennsylvanian (Nance 1987; Waldron et al. 2007). It is difficult to constrain the exact timing of fault motion, but the $\sim 8 \mathrm{~km}$ thickness of Carboniferous (Viséan to Duckmantian) strata in the Cumberland Basin attest to significant and ongoing faultinduced subsidence throughout its history (Calder, 1994).

The thickest occurrences of the Springhill Mines Formation occur in the Athol Syncline, a salt withdrawal minibasin that developed in the western Cumberland Basin as sediments shed from the adjacent highlands caused differential loading of the underlying Windsor Group evaporites (Waldron and Rygel 2005; Waldron et al. 2013). Coal seams of economic thickness within the Springhill Mines Formation occur only in the Athol Syncline and are thickest within the Coal Mine Brook member adjacent to the Black River diapir (Calder 1995), suggesting that accommodation associated with salt withdrawal may have favored the development and preservation of thick peats. Halokinetic accommodation may have been particularly important for peat development within the syncline because the development of rheotrophic mires at Springhill also appears to have been controlled by groundwater discharge at the toes of basin-margin alluvial fans (Calder et al. 1991; Calder 1994). The relationship between halokinesis and peat accumulation is further supported by the progressive spatial and temporal shift in the "coal window" from the older Joggins Formation (early Langsettian) along the coast to the younger Springhill Mines Formation (middle Langsettian) in the east (Calder 1994; Calder and Gibling 1994), a trend that matches well the timing and location of salt withdrawal (Waldron et al. 2013).

\section{Stratigraphy}

\section{History of stratigraphic nomenclature}

The "Joggins section" is a $\sim 4.5 \mathrm{~km}$ thick, nearly continuous exposure of dipping Carboniferous rocks exposed along the southern shore of Chignecto Bay (the northern arm of the Bay of Fundy). The Joggins Fossil Cliffs UNESCO World Heritage Site includes $\sim 3.5 \mathrm{~km}$ of strata below Ragged Reef Point (Fig. 1). These strata were originally measured by William Logan in June 1843, and his work remains the only complete description of the coastal exposure of the Springhill Mines Formation (Logan 1845; Rygel and Shipley 2005). Logan subdivided his section into eight divisions based on major lithological changes; his divisions are the basis for most of the major stratigraphic subdivisions recognized today (Fig. 4; Ryan et al. 1991). The interval described in this paper corresponds to Logan's Division 3, which he described as an interval 2134 foot, 1 inch $(650.5 \mathrm{~m})$ thick containing red, green, and grey mudrocks, carbonaceous shales, sandstone, and 22 coal seams with an aggregate thickness of 5 feet, 5 inches ( 1.65 $\mathrm{m})$. This interval was distinguished from underlying strata in Division 4 (Joggins Formation) by the higher percentage of red mudrocks and absence of limestones. Unlike the redbeds and relatively coarse-grained sandstones in strata of the overlying Division 2 (Ragged Reef Formation), Division 3 (Springhill Mines Formation of Davies et al. 2005) contains abundant green and grey intervals and lacks conglomeratic sandstones.

Strata of Division 3 were subsequently assigned to the Middle Grindstone Division (Bell 1912), the Joggins Formation (Bell 1914), the "Coarse Fluvial Facies" (Belt 1964), and various informal units within the undivided Cumberland Group (Shaw 1951a, b; Copeland 1959; Kelley 1967; Howie and Barss 1975). Ryan et al. (1991) greatly simplified the stratigraphy in the Cumberland Basin, brought it in line with the North America Stratigraphic Code, and reaffirmed the utility of Logan's (1845) divisions with their adoption of formations that have contacts at or near Logan's division boundaries. Measured sections presented in Ryan et al. (1991) and related works (Ryan et al. 1990a, b; Ryan and Boehner 1994) are largely redrawn from Logan (1845), a testament to the importance and quality of his initial work. In their formal description of the Springhill Mines Formation, Ryan et al. (1991) defined a composite type section from the Springhill area using a series of drill cores. Ryan et al. (1991) defined a reference section along the coast and described it as having a basal contact at the base of a sandstone 168 feet, 2 inches $(\sim 51.3 \mathrm{~m})$ above the base of Division 3 (the top of the uppermost limestone in the section). Although the exact placement was not specified, the upper contact of Ryan et al.'s coastal reference section for the Springhill Mines Formation appears to correspond to the top of a dark mudrock that caps Logan's Division 3. Calder (1991) assigned the thin coals and red and grey mudrocks that overlie the thick coals and exclusively grey mudrocks at Springhill to his Lithofacies Assemblage V, informally named the MacCarrons River member of the Springhill Mines Formation, in recognition of their correlation and excellent exposure in the coastal section south of Joggins. This informal subdivision was also shown on diagrams in Ryan et al. (1991), but not formally defined. Davies et al. (2005) favored Logan's (1845) definition and placed contact between the Joggins and Springhill Mines Formation at the top of the uppermost limestone in Division 3 (915.5 $\mathrm{m}$ in their section). 


\section{Proposed revisions}

We redefine the Joggins Formation as a coal-bearing part of the Cumberland Group that contains red, green, and grey mudrocks, sandstones, and assemblages of interbedded bivalve-bearing limestones, dark shales, and sharp-based sandstones assignable to the open water facies association (OWFA) of Davies and Gibling (2003) and Davies et al. (2005). This redefinition places the Joggins-Springhill Mines contact $16.9 \mathrm{~m}$ higher in the section and puts all OWFA deposits within the Joggins Formation, which is now 932.4 $\mathrm{m}$ thick at the type section (see details in Appendix 3).

We also formally define the MacCarrons River Member of the Springhill Mines Formation which contains thin coals, sandstones, and red, green, and grey mudrocks and lacks OWFA deposits including limestones (Appendix 2). This member comprises the entirety of the coastal exposure of the Springhill Mines Formation. It extends from the newly modified lower boundary to the base of a large multistorey sandstone that contains the lowest extraformational gravel (quartz granules to $4 \mathrm{~mm}$ ) above the coal-bearing part of the Cumberland Group. The base of this channel sits atop a gleyed interval that likely corresponds to the 2-foot-thick (0.61-m-thick) carbonaceous shale at the top of Logan's (1845) Division 3.

\section{Distribution and correlation}

Regionally, the Springhill Mines Formation conformably overlies the Joggins Formation and has a gradational to interbedded contact with overlying strata of the Ragged Reef Formation (Ryan et al. 1991; Calder 1995). Near the southern margin of the basin, subsurface data show that coal-bearing strata of the Springhill Mines Formation are interbedded with conglomeratic facies of the Polly Brook Formation along the flanks of the Cobequid Highlands (Ryan et al. 1991; Calder 1994). Although this unit has been tentatively correlated with the Grande Anse Formation of New Brunswick (Keighley et al. 2008), exact stratigraphic relationships are unclear because of structural complications, insufficient biostratigraphic control, and loss of exposure beneath the Bay of Fundy.

\section{Age}

The Springhill Mines Formation, along with much of the coal-bearing middle part of the Cumberland Group, has long been assigned an early Westphalian age based on macroflora and palynology (Bell 1943; Hacquebard and Donaldson 1964; Dolby 1991; Utting and Wagner 2005). From detailed palynological sampling of the 660-m-thick Springhill Mines Formation at Springhill, Dolby (1991) interpreted the age of the formation to be late Langsettian to early to middle Duckmantian. Recently, Utting et al. (2010)

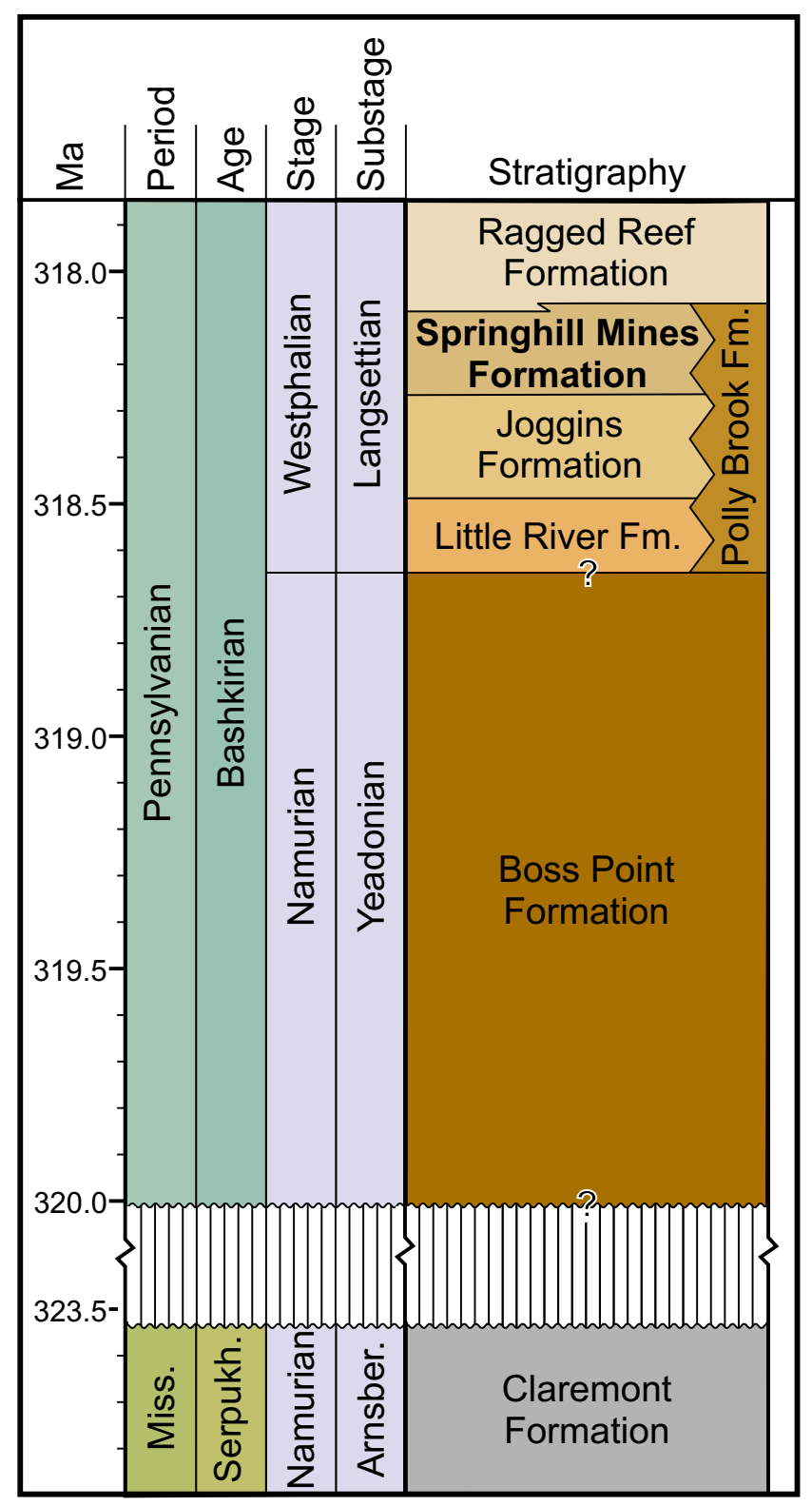

Figure 4. Diagram showing the age and stratigraphic relationships between many of the units exposed in the Joggins section. All of the Pennsylvanian units are part of the Cumberland Group; the Claremont Formation is the uppermost unit in the Mabou Group. Modified after Ryan et al. (1991), St. Peter and Johnson (2009) and the graphic depiction of stratigraphic units relative to named subdivisions of time shown in Figure 14 of Utting et al. (2010). Numeric dates derived from TS Creator software (Ogg and Lugowski 2014) which uses data from Gradstein et al. (2012) and has radiometric dates that differ considerably from recent publications on the Cumberland Group (Allen et al. 2013; Waldron et al. 2013). 
assigned the Boss Point and Little River formations to the Raistrickia saetosa spore zone (Yeadonian to Langsettian) and the Joggins, Springhill Mines, and Ragged Reef formations to the Raistrickia fulva spore zone (Langsettian). Assuming uniform subsidence rates, a Yeadonian- Langsettian boundary that occurs at the base of the Little River Formation, and that the Langsettian lasted $\sim 1.36$ million years (Ogg and Lugowski 2013; Fig. 4), the $697 \mathrm{~m}$ thick coastal exposure of the Springhill Mines Formation would have been deposited in $\leq 0.31$ million years (a subsidence rate of $2.2 \mathrm{~mm} / \mathrm{yr}$ ). Although recent revisions to the geologic time scale have shortened the duration of the Langsettian (Davydov et al. 2004; Ogg and Lugowski 2013) and thus increased the apparent subsidence rate, the calculated value is still well within the range for other halokinetic minibasins (Rowan 1995; Poliakov et al. 1996; McBride et al. 1998).

\section{Previous Sedimentological Studies}

Despite the relatively complete and accessible nature of the exposure, the coastal outcrop of the Springhill Mines Formation has been examined by only a few authors. The first and only examination of the whole interval was the reconnaissance work of William Logan during the summer of 1843 (Logan 1845). Logan measured 3900 feet (1189 m) of section in his Division 4 (Joggins Formation) and Division 3 (Springhill Mines Formation of Davies et al. 2005) on 8 June 1843 (Rygel and Shipley 2005). Although the coal-bearing strata of the underlying Joggins Formation was the subject of numerous studies in the following decades (Grey and Finkel 2011), the Springhill Mines Formation was largely ignored. Way (1968) studied a $\sim 250 \mathrm{~m}$ interval (at $175-425 \mathrm{~m}$ in our section) and determined that the strata represent the channel, floodplain, levee, and backswamp deposits of a meandering fluvial system. Kaplan (1980) examined a $\sim 300 \mathrm{~m}$ interval immediately south of MacCarrons River (183-483 m in our section) and interpreted it as a meandering fluvial system with abundant channel, floodplain, lacustrine, and crevasse splay deposits (Kaplan and Donahue 1980). The coals were interpreted as wholly terrestrial and their anomalously high sulfur values were attributed to diagenetic enrichment by brines derived from the underlying Windsor Group (Kaplan 1980). The coals were also enriched in nickel, manganese, lead, and other heavy metals that may have been derived from the adjacent highlands (Kaplan et al. 1985).

Rust et al. (1984) studied a $\sim 680 \mathrm{~m}$ interval between MacCarrons River (183 m in our section) and the southern side of Ragged Reef Point (170 m above the Springhill MinesRagged Reef contact). These authors interpreted many of the channel bodies in this interval as having been deposited in an anastomosed river system on the basis of their relatively low width:thickness values and internal architecture. Rust et al.
(1984) noted that a few of the anastomosed-channel bodies contained lateral accretion deposits in their upper portions, and that the upper $100 \mathrm{~m}$ of their study interval (all within the Ragged Reef Formation) recorded a transition from anastomosed-channel deposits to meandering-channel deposits. They interpreted sandy overbank deposits, many of which contain standing lycopsids, as levees and crevasse splays. Fine-grained deposits included green, grey, and red mudrocks, carbonaceous shales, and thin coal seams. They attributed the upward increase in redbeds and decrease in coal seams as a consequence of steepening of the alluvial plain and lowering of the groundwater table.

Ryan et al. (1991) reintroduced Logan's (1845) written section as a graphic log and used it as the basis for redefining the stratigraphy in the Cumberland Basin. Ryan and Boehner (1994) later interpreted the coastal exposure as recording a northeasterly flowing trunk river system that was blocked by alluvial fans derived from the Cobequid Highlands to the south. They postulated that this blockage may have caused a local rise in base level, which contributed to peat accumulation and the development of an anastomosed fluvial system.

Smith (1991) examined paleosols in the Joggins and Springhill Mines formations in an attempt to reconstruct floodplain dynamics and paleoclimate. He described three paleosol sequences within the Springhill Mines Formation, which he interpreted as recording the transition from a semiarid, seasonally wet-dry climate (his part III; uppermost Joggins formation to $383 \mathrm{~m}$ in our section) to more humid conditions (his part IV; $\sim 383$ to $697 \mathrm{~m}$ in our section). Smith's paleoclimatic interpretation seemingly contradicts the upward increase in redbeds documented by Rust et al. (1984) and verified in this study (Fig. 3), a discrepancy that we attribute to Smith's limited sampling of this thick (and largely undescribed) interval and the red, till-derived wash on the cliffs in the lower part of the section.

Falcon-Lang (1999) and Falcon-Lang and Scott (2000) examined the thick sandstone just north of MacCarrons River (166-176 $\mathrm{m}$ in our section) and, based on the presence of ridge and swale topography, interpreted it as a channel body formed by a meandering river system. This channel body contains fossil charcoal and transported cordaitalean trunks that may have been transported downstream from upland areas when fires destabilized slopes.

In an overview of the regional fluvial sedimentology, Allen et al. (2011, 2013) supported Rust et al.'s (1984) interpretation of the Springhill Mines Formation as recording a progressive shift from fixed- to meandering-channel bodies. They interpreted fluvial architecture and geometry as being compatible with prevailing interpretations of a (sub)humid seasonal climate during deposition of this unit (Calder 1994, 1998; Falcon-Lang and Scott 2000; Utting et al. 2010). 


\section{FACIES ASSOCIATIONS}

The strata described in this paper include a $16.9 \mathrm{~m}$ interval reassigned to the top of the Joggins Formation (915.5 to $932.4 \mathrm{~m}$ ) which is overlain by a $697-\mathrm{m}$-thick exposure of the Springhill Mines Formation. The facies association nomenclature was derived from Davies and Gibling (2003) and Davies et al. (2005); although this terminology works well and allows for direct comparison between these units, important differences exist (Table 1). The descriptions and interpretations that follow were derived from the detailed measured section presented in Appendix 3.

The measured section was constructed by direct measurement of beds exposed in the cliff and the use of a Jacob's staff and/or laser rangefinder for intervals that were covered or exposed only in the intertidal zone $(60.8 \mathrm{~m}$; 9\% of the thickness of the Springhill Mines Formation). All units were measured to the nearest $0.01 \mathrm{~m}$ in the field. Thicknesses for clastic units are reported to the nearest 0.1 $\mathrm{m}$ and thicknesses for organic-rich units are reported to the nearest $0.01 \mathrm{~m}$. Reported thicknesses of facies associations include channel bodies and covered intervals contained therein. Channel bodies are identified by the meterage value at the top of the body; their stratigraphic position is used as a way to link the measured section (Fig. 4 and Appendix 3) to the map of the intertidal zone provided in Fig. 3.

\section{Open Water Facies Association (OWFA)}

\section{Description}

The single occurrence of the open water facies association (OWFA) at the base of the measured section is assigned to the top of the Joggins Formation (915.5 to $932.4 \mathrm{~m}$ ). Constituent lithofacies include grey mudrocks, very-fine- to fine-grained sheet sandstones, and thinly interbedded packages of sandstone and mudrock (Fig. 5). This interval has a sharp contact with the underlying carbonaceous limestone and the overlying poorly drained facies association (PDFA) at the base of the Springhill Mines Formation.

Grey silty mudstone is the most abundant lithofacies within this occurrence of the OWFA. Textures range from fissile to platy; laminated intervals are present locally. Siderite occurs as scattered, flattened nodules dispersed within mudrock and as flattened nodules in discrete bands. Veryfine- to fine-grained sheet sandstones are interbedded with the mudrocks. Sandstones occur throughout and become particularly abundant near the top of this interval ( 927.5 to $932.4 \mathrm{~m}$ ). Most are tabular sheet sandstones with sharp basal contacts and sharp to interbedded upper contacts. Some sandstones are underlain by, and/or pass upward into packages of thinly interbedded sandstone and mudrock. Sedimentary structures within sandstones include ripple crosslaminae, ball-and-pillow structures, and convolute laminae.
The upper surfaces of some sandstones are ornamented with symmetric ripples; lower surfaces may contain tool marks. A sandstone channel body is present in the intertidal zone at a level broadly equivalent to the top of the sand-rich interval at $\sim 932.3 \mathrm{~m}$.

Body fossils are common in this OWFA interval; they include ostracods, bivalves, fish bones, abundant unidentifiable plant fragments, and scattered large plant fragments (cordaite leaves, Artisia, lycopsid bark, and fern fragments). In-situ carbonized roots and Stigmaria are present in the sand-rich interval above $927.5 \mathrm{~m}$. Trace fossils include Kouphichnium (932.3 m) and Selenichnites (916.8 m).

\section{Interpretation}

These platy to laminated mudrocks record suspension deposition in standing water that experienced very modest wave activity and was of sufficient depth to limit plant growth (Davies et al. 2005). Sandstones, most of which are sharp-based and contain both uni- and bidirectional ripple marks, represent prograding mouth-bar deposits or storm beds emplaced by hyperpycnal flows (Davies and Gibling 2003). The presence of a channel body at $\sim 932.3 \mathrm{~m}$ and progressive increase in sandstone and root abundance above $927.5 \mathrm{~m}$ records the ultimate infilling of this body of water via progradation of floodplain facies.

Although long regarded as nonmarine, a growing body of evidence suggests that this facies association records deposition in a bay or gulf that had at least a distal connection to marine waters (Calder 1998; Davies and Gibling 2003; Davies et al. 2005). Archer et al. (1995) interpreted similar intervals as brackish, based on the presence of possible agglutinated foraminifera and the trace fossils Kouphichnium (interpreted as horseshoe-crab trackways) and Cochlichnus. Faunal assemblages within Joggins OWFA limestones have been variously interpreted as recording marine to lacustrine conditions (Duff and Walton 1973; Vasey 1984; Brand 1994; Skilliter 2001). Tibert and Dewey (2006) interpreted ostracods similar to the ones observed in this interval as recording marginal marine conditions. Most recently, Grey et al. (2011) documented echinoderms and punctuate brachiopods in the oldest OWFA deposits in the Joggins Formation; they interpreted faunal changes in the overlying OWFA deposits as recording a progressive decrease in marine influence. Taken together, the sedimentological and paleontological evidence suggests a distant connection to the ocean and a body of water that may have been broadly comparable to the modern Black Sea or the Neogene Pannotian Basin (Davies and Gibling 2003; Davies et al. 2005; Dolton 2006).

The base of the limestone at $\sim 915.12 \mathrm{~m}$ in the Joggins Formation represents a flooding surface and the base of a fifteenth cycle in this unit (Davies et al. 2005). The overlying dark shales and sharp-based sandstones (915.5-932.4 m) are 
Table 1. Summary of non-channel facies associations in the measured section. Channel bodies (CB) makes up a total of $103.4 \mathrm{~m}$ (15\%) of the measured section through the Springhill Mines Formation and are summarized in Table 2. Covered intervals total $60.8 \mathrm{~m}$ ( $9 \%$ of the thickness of the Springhill Mines Formation).

\begin{tabular}{|c|c|c|c|c|}
\hline Unit & Facies Association & Lithologies & Fossils & $\begin{array}{c}\text { Thickness, Abundance, and } \\
\text { Distribution }\end{array}$ \\
\hline \multirow[b]{2}{*}{$\begin{array}{l}\text { Springhill } \\
\text { Mines } \\
\text { Formation }\end{array}$} & $\begin{array}{l}\text { Well Drained Facies } \\
\text { Association (WDFA) }\end{array}$ & $\begin{array}{l}\text { Reddish brown mudrocks; generally blocky but may be platy } \\
\text { locally (especially at the bottom of beds). Scattered pedogenic } \\
\text { slickensides and calcareous nodules. Minor green/grey and } \\
\text { organic-rich bands present locally. } \\
\text { Sandstones include minor channel bodies, sheets, and interbeds } \\
\text { within heterolithic intervals. Sheets and interbeds contain ripple } \\
\text { cross-laminae, centroclinal cross-strata, mudstone-filled } \\
\text { hollows, and may thin across outcrop belt. }\end{array}$ & $\begin{array}{l}\text { Tetrapod trace fossils: Matthewichnus, } \\
\text { Pseudobradypus, Limnopus, Batrachichnus, and } \\
\text { Salichnium } \\
\text { Invertebrate trace fossils: Diplichnites gouldi in } \\
\text { sheet sandstones. Diplichnites gouldi, } \\
\text { Diplichnites cuithensis, and Kouphichnium in } \\
\text { association with channel bodies. } \\
\text { Plant fossils: in-situ and transported lycopsids } \\
\text { and calamites, Stigmaria, permineralized } \\
\text { cordaite logs in channels, cordaite leaves }\end{array}$ & $\begin{array}{l}\text { Eight occurrences ranging } \\
\text { from } 20.0-156.7 \mathrm{~m} \text { thick } \\
\text { ( } 390.4 \mathrm{~m} \text { total; } 56 \% \text { of } \\
\text { formation thickness). } \\
\text { Present throughout, but } \\
\text { becomes thickest and most } \\
\text { abundant above } 297 \mathrm{~m} \text {. }\end{array}$ \\
\hline & $\begin{array}{l}\text { Poorly Drained Facies } \\
\text { Association (PDFA) }\end{array}$ & $\begin{array}{l}\text { Green to grey mudrocks; generally blocky although some platy } \\
\text { to laminated intervals present locally. } \\
\text { Organic-rich intervals including thin coals ( } 28 \text { seams, }<18 \mathrm{~cm} \\
\text { thick), carbonaceous shales ( } 17 \text { occurrences, }<75 \mathrm{~cm} \text { thick), and } \\
\text { organic-rich bands within mudrocks ( } 32 \text { occurrences, }<5 \mathrm{~cm} \\
\text { thick). } \\
\text { Sandstones include minor channel bodies, sheets, and interbeds } \\
\text { within heterolithic packages. Sheets and interbeds contain } \\
\text { ripple cross-laminae; centroclinal cross-strata and mudstone- } \\
\text { filled hollows present locally. }\end{array}$ & $\begin{array}{l}\text { Tetrapod trace fossils: Batrachichnus, } \\
\text { Limnopus, Salichnium, Matthewichnus, and } \\
\text { Notalacerta } \\
\text { Invertebrate trace fossils: Kouphichnium, } \\
\text { Diplichnites cuithensis, Diplichnites gouldi, } \\
\text { Cochlichnus. } \\
\text { Plant fossils: Stigmaria, in-situ lycopsids, } \\
\text { calamites, cordaite leaves, carbonized roots, } \\
\text { small unidentifiable plant fragments, and } \\
\text { cordaitalean-like trees locally. }\end{array}$ & $\begin{array}{l}\text { Eight occurrences ranging } \\
\text { from } 5.0-74.4 \mathrm{~m} \text { thick ( } 142.5 \\
\mathrm{~m} \text { thick; } 20 \% \text { of formation } \\
\text { thickness). Present } \\
\text { throughout the formation, } \\
\text { but thickest and most } \\
\text { abundant below } 506 \mathrm{~m} .\end{array}$ \\
\hline $\begin{array}{l}\text { Joggins } \\
\text { Formation }\end{array}$ & $\begin{array}{l}\text { Open Water Facies } \\
\text { Association (OWFA) }\end{array}$ & $\begin{array}{l}\text { Dark grey mudrocks with laminated to platy textures. } \\
\text { Sharp-based sheet sandstones with ripple cross-laminae, soft- } \\
\text { sediment deformation structures, and symmetric ripples. }\end{array}$ & $\begin{array}{l}\text { Body fossils: ostracods, bivalves, fish bones } \\
\text { Invertebrate trace fossils: Kouphichnium and } \\
\text { Selenichnites } \\
\text { Plant fossils: Cordaites, Artisia, lycopsid bark, } \\
\text { fern fragments, Stigmaria, and carbonized roots }\end{array}$ & $\begin{array}{l}\text { Single occurrence in the study } \\
\text { interval has been reassigned } \\
\text { to the top of the Joggins } \\
\text { Formation }(915.5-932.4 \mathrm{~m}) \text {. }\end{array}$ \\
\hline
\end{tabular}

genetically related to this flooding event and record infilling of the resulting water body. The OWFA interval described herein is lithologically identical to those in the underlying Joggins Formation and is unlike any lithologies present in overlying strata of the Springhill Mines Formation. The lithologic similarity and genetic relationship to underlying strata is the primary reason for reassigning this interval to the Joggins Formation.

\section{Poorly Drained Facies Association (PDFA)}

\section{Description}

Eight occurrences of the poorly drained facies association (PDFA) are present in the measured section (total of 142.5 $\mathrm{m} ; 20 \%$ of formation thickness). Six examples are between 5.0 and $11.6 \mathrm{~m}$ thick; two particularly thick occurrences are present at 223.1 to $297.5 \mathrm{~m}$ (74.4 m thick) and 479.0 to $506.0 \mathrm{~m}$ (27.0 m thick). Common lithofacies include green and grey mudrock, sheet sandstones, carbonaceous shales, thin coals, and scattered channel bodies (Fig. 6). The contact between over- and underlying occurrences of the well drained facies association (WDFA) is based on the dominance of green/grey colors and relative abundance of organic-rich facies. Contacts with the WDFA are commonly gradational and their placement is thus approximate.
Green to grey silty claystones to mudstones are the most common lithofacies in the PDFA ( $60 \%$ of PDFA thickness). Beds of mudrock range from 0.2 to $4.5 \mathrm{~m}$ thick; contacts with other lithologies are sharp to gradational over a few centimeters. Most mudrocks are internally massive (particularly those beneath organic-rich horizons), although some grey intervals are platy to laminated. Possible pedogenic slickensides are present at $488.5 \mathrm{~m}$. Flattened siderite nodules are common and may be isolated or in discontinuous bands; some siderite nodules have a vertical orientation and are developed around carbonized roots. Red mottles within green and grey mudrocks are present locally, as are scattered thin intervals of red mudrock ( $<5 \%$ of PDFA thickness). A pyrite nodule was present in reddish beds near the top of a PDFA occurrence at $10 \mathrm{~m}$.

Abundant organic material is present in the PDFA as thin coals ( 29 occurrences; $<18 \mathrm{~cm}$ thick), carbonaceous shales (17 occurrences; $<75 \mathrm{~cm}$ thick), and organic-rich horizons within mudrocks ( 32 occurrences; $<5 \mathrm{~cm}$ thick). Most coal seams are less than $5 \mathrm{~cm}$ thick; an $18 \mathrm{~cm}$ thick example is present within a thick PDFA interval at $\sim 268.8 \mathrm{~m}$. Coals commonly occur in closely spaced zones separated by mudrock interbeds. Carbonaceous shales are dark grey to black, fissile/laminated, and are commonly $<10 \mathrm{~cm}$ thick; particularly thick examples include a $75-\mathrm{cm}$-thick bed at $\sim 6 \mathrm{~m}$ and a $26-\mathrm{cm}$-thick bed at $\sim 117.7 \mathrm{~m}$. Most carbonaceous shales have a sharp basal 
contact; upper contacts are commonly gradational if overlain by coals and sharp if overlain by sandstones or mudrocks. Organic-rich horizons locally cap packages of green/grey, blocky mudrocks.

Sandstones are present as channel bodies (5\% of PDFA thickness in the line of section), sheets (25\% of PDFA thickness), and as thin beds within heterolithic packages of interbedded sandstone and mudrock (10\% of PDFA thickness). Seven channel-body sandstones occur within the PDFA; two were fixed-channel bodies and five were not sufficiently exposed to be classified (see Channel Bodies section below). Sheet sandstones range in thickness from $0.05 \mathrm{~m}$ to $1.3 \mathrm{~m}$ and commonly have sharp upper and lower contacts. Heterolithic packages contain thin interbeds of sandstone and mudrock and range from 0.5 to $5.0 \mathrm{~m}$ thick. Both sheet sandstones and heterolithic packages can change significantly in thickness across the outcrop belt, and they may be laterally adjacent to channel bodies. Internally, both types range from massive to thinly bedded. Ripple crosslaminae are common; cross-beds and centroclinal crossstrata may be developed locally. Many sheet sandstones show destruction of bedding by roots and pedogenesis.

Tetrapod trackways are locally abundant and include
Batrachichnus, Salichnium, Limnopus, Matthewichnus, and Notalacerta. Diplichnites gouldi is the most abundant invertebrate trace fossil from floodplain facies, although both it and Diplichnites cuithensis are locally common near the tops of channel bodies in the PDFA. The sheet sandstone at $13 \mathrm{~m}$ contains Kouphichnium, Diplichnites gouldi (underprints), Cochlichnus, and an in-situ Stigmaria.

Plant fossils are common in the PDFA, especially in beds closely associated with coals, carbonaceous shales, and organic-rich horizons. Stigmaria, siderite rhizoconcretions, and vertical carbonized roots are common in mudrocks, particularly those beneath horizons with abundant organic material. Strata deposited atop coals, carbonaceous shales, or organic-rich horizons commonly entomb insitu lycopsids and calamites (Fig. 6b). Although many sandstone-cast lycopsids have vascular traces in vertical files ("Syringodendron" condition) suggestive of Sigillaria (see Calder et al. 2006 for discussion), other genera are represented locally (Fig. 6d). A single charcoal-filled lycopsid stump similar to the tetrapod-bearing specimens in the underlying Joggins Formation is present at $\sim 223.5 \mathrm{~m}$. Many clastic intervals contain mudstone-filled hollows found in close association with poorly preserved plant fossils

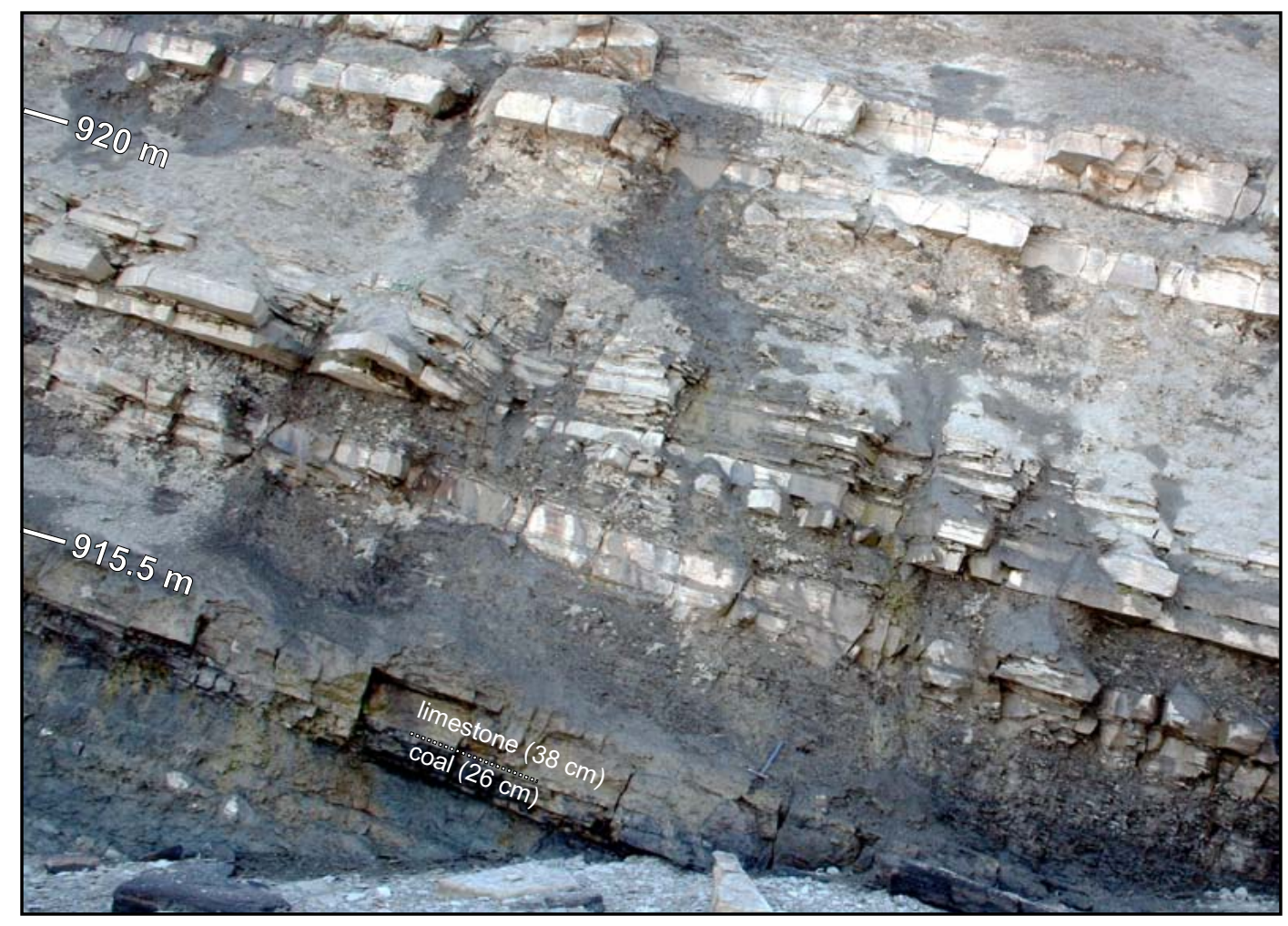

Figure 5. Outcrop exposure of the open water facies association (OWFA) at the base of the measured section. Davies et al. (2005) placed the contact between the Joggins and Springhill Mines Formation atop the 38-cm-thick limestone; we move it $16.9 \mathrm{~m}$ upsection to the top of the uppermost sharp-based sandstone. Strata atop the coal and limestone largely consist of grey mudrocks and sandstones that were deposited below storm wave base in a marginal marine bay or lagoon. 

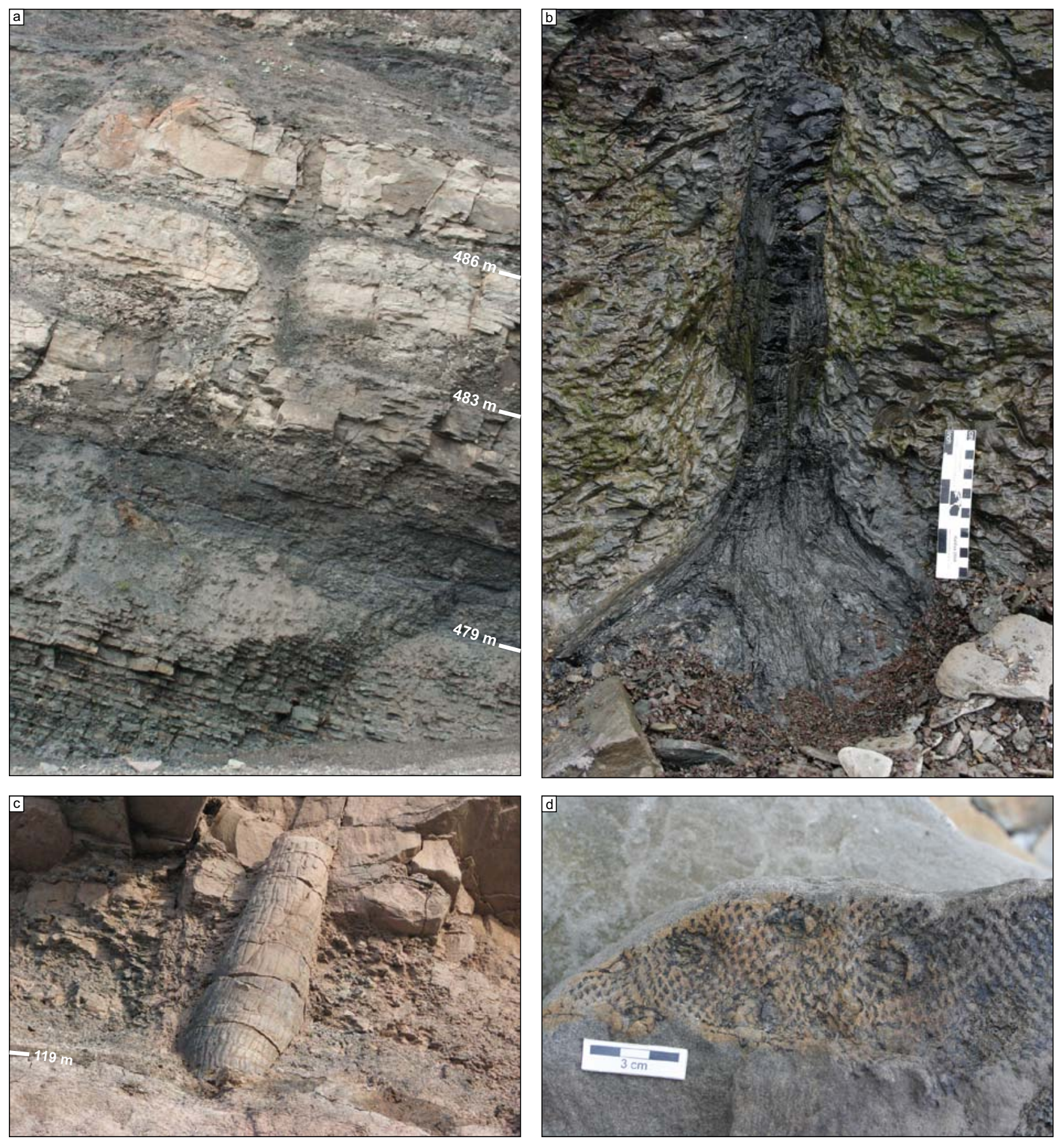

Figure 6. Features of the poorly drained facies association (PDFA). (a) Photograph of $\sim 477-488 \mathrm{~m}$ in the measured section showing typical PDFA facies (strata above the $479 \mathrm{~m}$ mark). Interbedded sandstones and mudrocks (levee deposits) below $479 \mathrm{~m}$ are overlain by interbedded green/grey mudrocks, organic-rich horizon, and thin coals (479$480.2 \mathrm{~m}$ ) deposited in relatively distal portions of the floodplain. These relatively fine-grained deposits are overlain by a series of coarsening-upward successions (mudrock passing into coarse-grained sandstones) that mark the periodic influx of sand. Note the entombed lycopsid and overlying mudstone-filled hollow between 483 and $486 \mathrm{~m}$. (b) Possible mangrove-like cordaitalean at $261.5 \mathrm{~m}$. Nearly identical plant fossils were described by Dawson (1868) and Falcon-Lang (2005); they were interpreted as representing plants that lived in a coastal area that was regularly inundated by brackish water. (c) Upright lycopsid preserved in a carbonaceous shale associated with the fossil forest at 116-121 m. The tree is rooted in a 7.5- $\mathrm{cm}$ sigillarian carbonaceous shale and entombed by green mudrock and a sheet sandstone. Like much of the section, wash from the overlying till gives the rocks a reddish cast. (d) Transported bark showing branch scars and leaf-cushion-scar pattern most likely from Bothrodendron, a non-sigillarian lycopsid. 
(Fig. 6a; Rygel et al. 2004). An enigmatic in-situ cordaitaleanlike tree, cruciform in transverse section and evocative of those described by Dawson (1868) and Falcon-Lang (2005) was present at $261.5 \mathrm{~m}$ (NSM011.GF.025.001). This specimen was rooted in an organic-rich horizon, entombed by grey mudrocks with abundant transported cordaite leaves and overlain by a thin sandstone with Kouphichnium preserved in hypycnal relief. Transported plant fossils include lycopsid bark impressions, calamites, and unidentifiable plant fragments.

\section{Interpretation}

The blocky green and grey mudrocks that make up the majority of the PDFA represent immature hydromorphic paleosols that were sufficiently waterlogged to allow for modest amounts of organic preservation within clastic paleosols (Stevenson 1969). Laminated carbonaceous shales and grey mudrocks record suspension deposition in floodplain lakes; these intervals were buried quickly enough to protect them against subsequent pedoturbation. The ubiquity of siderite nodules and rhizoconcretions in mudrocks suggests inundation by fresh water; this is because the low levels of dissolved sulfate in fresh water favor the development of siderite over pyrite (Pye et al. 1990). The presence of reddish brown mudrocks within PDFA intervals records either transport of reddened sediment into swampy areas (Davies et al. 2005) or localized changes in drainage conditions.

Coal seams in the coastal exposure of the Springhill Mines Formation are relatively thin. They likely formed after rheotrophic mires (Calder 1994; Hower et al. 2000) and their modest thickness compared to the 4-m-thick seams at Springhill likely reflects a combination of decreased halokinetic accommodation and distance from groundwater discharge sites along the basin margin (Calder 1994). The parent peats, and many of the carbonaceous shales developed atop rooted intervals, likely represent local features that developed on poorly drained portions of the floodplain (Smith 1991; Beuthin and Blake 2002). The modest thickness of the seams $(\leq 18 \mathrm{~cm})$ and apparent abundance of Sigillaria suggest that these relatively shortlived peat-forming wetlands represent the pioneering ecotonal element of longer-established mires of the Coal Mine Brook member at Springhill (Calder 1993). Given their inferred rheotrophic nature, the mires represented by these thin coal beds may have been able to withstand a degree of seasonality (Phillips and DiMichele 1992; Calder 1993; Hower et al. 2000).

Abundant sandstone-cast lycopsid trunks, in-situ calamites, and stigmarian rhizomorphs are very common in green and grey overbank facies, suggesting that disturbanceprone clastic swamps were common in low-lying portions of the floodplain (sensu Gastaldo 1987; Calder et al. 2006).
Sheet sandstones and heterolithic packages of sandstone and mudrock record crevasse-splay and levee deposits, respectively. These sandy deposits formed when the channels that flowed through the PDFA overtopped their banks during flood events. Two fixed-channel bodies were preserved within the PDFA (six others could not be classified) suggesting that an anastomosed network of channels crossed these clastic swamps and poorly drained portions of the floodplain (see below).

The tetrapod-trackway assemblage is comparable to that of the underlying Joggins Formation and records an abundant and diverse tetrapod community that likely included temnospondyls, microsaurs, and possible early reptiles (Hunt et al. 2004; Cotton et al. 1995; Calder et al. 2006; Stimson et al. 2012). The local presence of possible mangrove-like cordaitaleans and Kouphichnium within the PDFA suggests that that the marine-influenced waters of the OWFA were in close proximity to this location during deposition of some wetland deposits (Archer et al. 1995; Falcon-Lang 2005; Carpenter et al. 2013).

\section{Well Drained Facies Association (WDFA) \\ Description}

Eight occurrences of the well drained facies association (WDFA) are present in the measured section (total of 390.4 $\mathrm{m}$; $56 \%$ of total thickness). Six occurrences are between 20 and $80 \mathrm{~m}$ thick; a $156.7-\mathrm{m}$-thick occurrence is present near the middle of the formation and a 107.5-m-thick occurrence is present at the top of the formation. Common lithofacies include reddish-brown mudrock, sheet sandstones, channel bodies, minor green and grey mudrocks, and scattered carbonaceous shales and organic-rich horizons (Fig. 7a). This facies association is distinguished by the dominance of red mudrocks, absence of coals, and relative scarcity of carbonaceous shales and organic-rich horizons. Contacts with the PDFA are commonly gradational and their placement is approximate.

Reddish-brown mudstones and siltstones range from $<0.01 \mathrm{~m}$ to $8.9 \mathrm{~m}$ thick and are the most abundant lithofacies in this facies association (Fig. $7 \mathrm{~b} ; \sim 35 \%$ of WDFA thickness). Contacts with other lithologies range from sharp to gradational over a few centimeters. Internal fabrics are generally blocky, although platy intervals may be present near the base of beds. Siderite nodules are present locally and rare calcareous nodules are present at $122.5 \mathrm{~m}$, $162 \mathrm{~m}$, and $204.5 \mathrm{~m}$ (Stage II of Machette 1985). Pedogenic slickensides are present at $227.9 \mathrm{~m}$ and $506.5 \mathrm{~m}$. Green and grey bands and/or mottles are common; many are associated with organic material (Fig. 7c). Green and grey mudrocks comprise less than $5 \%$ of the thickness of the WDFA.

Sandstones are present as channel bodies $(20 \%$ of WDFA thickness), sheets (20\% of WDFA thickness), and 

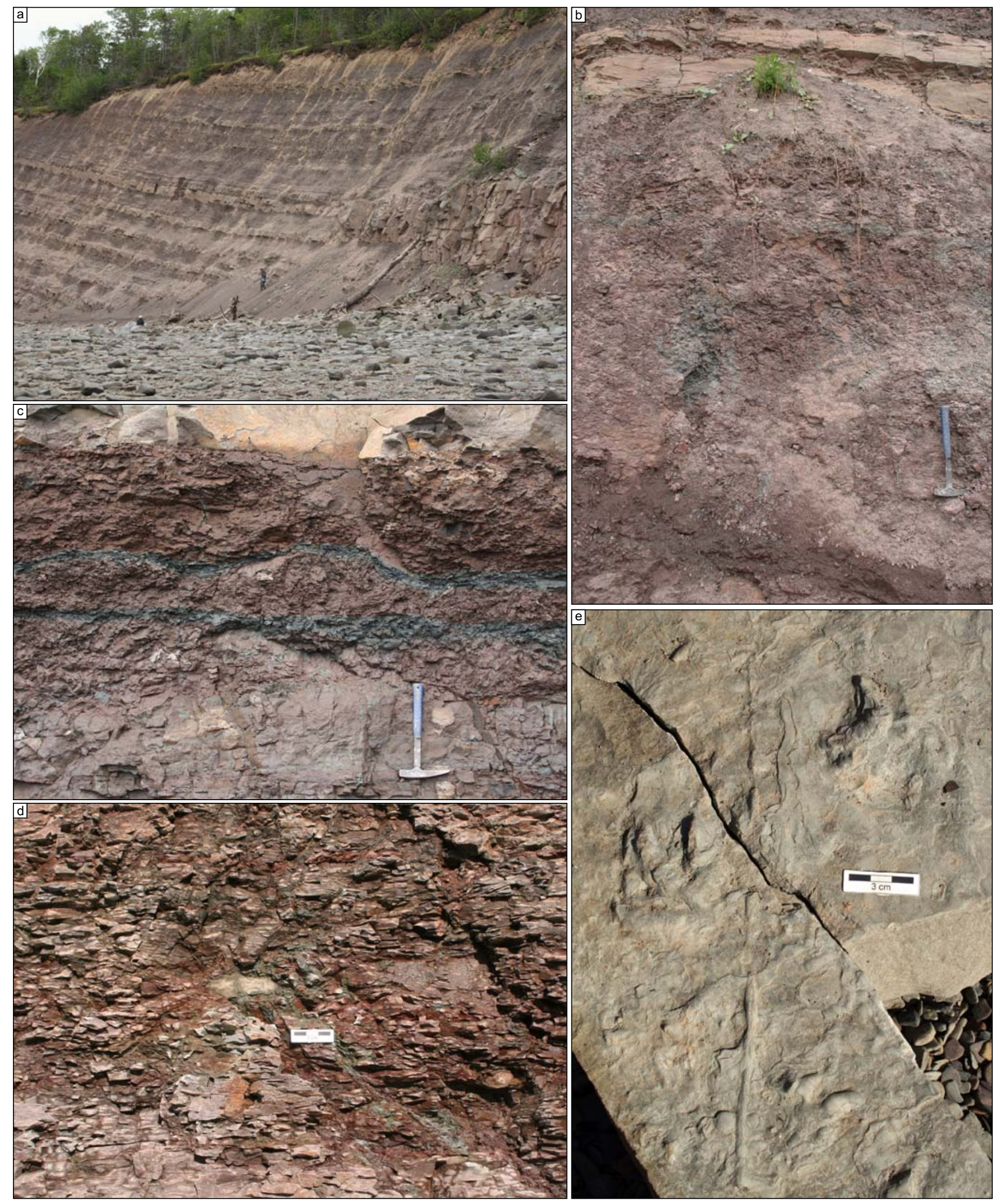
as thin beds within heterolithic packages of interbedded sandstone and mudrock (25\% of WDFA thickness). Twentynine channel-body sandstones occur within the WDFA; five are fixed-channel bodies, eight are meandering-channel bodies, four are sheets, and 12 were not well enough exposed to be classified (see Channel Bodies section below). Sheet sandstones range from $0.09 \mathrm{~m}$ to $1.8 \mathrm{~m}$ thick; they commonly have sharp upper and lower contacts. Heterolithic packages contain thin interbeds of sandstone and mudrock and range from 1.9 to $13.0 \mathrm{~m}$ thick. Both may be laterally adjacent to channel sandstones and exhibit marked thinning across the outcrop belt (Fig. 7a). Internally, sandstones range from massive (commonly with roots) to thinly bedded and laminated. Ripple cross-laminae are very common; crossbeds and centroclinal cross-strata are present locally.

Trace fossils are common in the WDFA, particularly in association with channel bodies and sheet sandstones. Tetrapod trackways are present at numerous intervals and include Matthewichnus, Pseudobradypus, Limnopus, Batrachichnus, and Salichnium (Fig. 7e). The invertebrate trackway Diplichnites gouldi is present in sheet sandstones at several levels, commonly in close association with tetrapod trackways. Redbed-channel bodies and heterolithic deposits at $106 \mathrm{~m}, 171-176 \mathrm{~m}$, and $525 \mathrm{~m}$ contain Kouphichnium, Diplichnites gouldi, and/or Diplichnites cuithensis.

In-situ plant fossils in overbank deposits include standing lycopsids and calamites, Stigmaria (Fig. 7d), and vertical carbonized roots. The MacCarrons River channel body at $175.5 \mathrm{~m}$ has in-situ lycopsids rooted in mudrocks that cap the main body. Overbank sandstones throughout the formation may include transported calamites, unidentifiable small plant fragments, and/or mudstonefilled hollows found in association with poorly preserved plant fossils. Coalified and transported lycopsid bark (flattened trunks?) may be locally abundant in some channel bodies; permineralized cordaitalean trunks are present in the MacCarrons River channel body (Falcon-Lang 1999; Falcon-Lang and Scott 2000), and sheet-like channel bodies at $386.5 \mathrm{~m}$ and $434.6 \mathrm{~m}$. A cordaite leaf impression was preserved in a sheet sandstone at $19 \mathrm{~m}$.

\section{Interpretation}

Strata of the WDFA were deposited in a floodplain environment where sediments experienced subaerial exposure and modest oxidation. Paleosols are cumulative and immature inceptisols to entisols; most did not have enough residence time on the floodplain to develop marked horizonation or obvious indicators of paleoclimate. A few sporadic and scattered calcareous nodules are present locally, an observation that Smith (1991) interpreted as evidence of wet-dry seasonality. The scarcity of pedogenic carbonate within redbeds suggests that significant carbonate development was prevented by high sedimentation rates and/or average rainfall in excess of $\sim 760 \mathrm{~mm}$ per year (Machette 1985; Royer 1999).

"Redbeds" in the Springhill Mines Formation are not the bright red color typical of strongly seasonal or desert environments, but rather are a reddish-brown color typical of sediment that experienced good drainage and modest, possibly sporadic, oxidation. The presence of insitu lycopsids and Stigmaria suggests that many of these intervals were clastic swamps formed in areas where water was generally available. Much of the reddening could have happened shortly after burial when changes in local drainage conditions may have resulted in oxidation of formerly green or grey sediments. During relatively dry periods, flora and fauna may have been concentrated close to active channels in a situation similar to the waterhole model described by Falcon-Lang et al. (2004). The presence of silicified cordaitalean logs in other Pennsylvanian units has been interpreted as recording increased aridity and/or a shift to better drained inland conditions (Gibling et al. 2010; Allen et al. 2011; Ielpi et al. 2014).

Channel bodies, sheet sandstones and heterolithic packages of sandstone and mudstone are relatively abundant in the WDFA. Channel bodies in the WDFA show a progressive transition from fixed to sheet to meandering types. Sheet sandstones represent crevasse splay sandstones and heterolithic intervals are interpreted as levee deposits formed in close proximity to channels. The relative abundance of sandy facies within red mudrocks beds suggests that the WDFA may record local drainage conditions developed on subtle topographic highs in areas close to channels (Smith 1991; Kraus 1999) and/ or in somewhat better drained areas updip of the PDFA. The presence of Kouphichnium in redbed-channel bodies (see below) suggests that at least some of the redbeds were deposited in close proximity to the coast and that the PDFA may have represented a relatively narrow paleogeographic belt.

Figure 7. (previous page) Features of the well drained facies association (WDFA). (a) Channel body at $306 \mathrm{~m}$ encased within reddish-brown mudrocks and sheet sandstones. Note the person for scale. (b) Detail of typical reddish-brown mudrock in the WDFA ( $\sim 312 \mathrm{~m})$ showing platy to blocky texture and diffuse green/grey mottles likely developed around organic material. (c) Detail of reddish-brown mudrock at the transition between PDFA and WDFA facies associations at $\sim 506 \mathrm{~m}$. Note the presence of slight organic-rich horizons and associated green/grey bands. (d) Sandstone cast Stigmaria in platy-to-blocky, reddish-brown mudrocks at $\sim 205.5 \mathrm{~m}$. Note green/grey zones developed around the carbonized roots that radiate out from the Stigmaria. (e) Tetrapod trackway with a pronounced tail drag preserved on the base of a sandstone at $\sim 213 \mathrm{~m}$. 


\section{CHANNEL BODIES (CB)}

Thirty-seven major channel bodies ( $>2 \mathrm{~m}$ thick) were described from the coastal exposure; several more inaccessible bodies present in the intertidal zone and high in the cliffs were not described. The 18 channel bodies within the line of section have a cumulative thickness of $103.4 \mathrm{~m}$ ( $15 \%$ of formation thickness). Channel bodies are composed of lithic arenites with abundant metamorphic grains and calcite cement. Although there is a slight upward increase in grain size, composition remains essentially unchanged throughout the formation. Paleoflow data were collected from each channel body and an average paleoflow direction was calculated using the most reliable indicators. Channelbody widths were measured using enlarged airphotos and/ or a laser rangefinder. True widths are reported if paleoflow data was available and both margins of the body were exposed. Maximum widths are reported if no paleoflow data is available but both margins are exposed; minimum widths were reported if one or both of the channel margins extends beyond the outcrop belt. We use Gibling's (2006) terminology for geometry, Holbrook's (2001) terminology for bounding surfaces, and Miall's (2006) terminology for lithofacies and macroforms. Twenty of the 37 major channel bodies were well enough exposed to allow classification into one of the categories described below (Table 2).

\section{Fixed-Channel Bodies}

\section{Description}

Eight fixed-channel bodies are present in the section; two occur in the PDFA and six occur in the WDFA (Figs. $8 \mathrm{a}, \mathrm{b})$. Additionally, many of the minor ( $<2 \mathrm{~m}$ thick), undescribed channel bodies within overbank deposits are fixed channels. Thicknesses range from 3.3 to $16 \mathrm{~m}(8.3 \mathrm{~m}$ avg.). The channel bodies at $47.5 \mathrm{~m}$ and $306 \mathrm{~m}$ have true width:thickness (W:T) values of 4.7, and 21.6, respectively; the other examples have minimum W:T values of 4 to 32 (Fig. 9). Fixed-channel bodies are bounded by fifth-order erosion surfaces that clearly incise into underlying/adjacent lithologies. Internally, some bodies have subhorizontal, fourth-order erosion surfaces that either onlap or parallel channel margins. Erosion surfaces are commonly lined with intraformational conglomerate composed of mud-chip ripup clasts and flattened siderite nodules. Channel bodies are filled with very-fine- to fine-grained sandstone; mudrockdominated intervals are present near the tops of the channel bodies at $306 \mathrm{~m}$ and $552.5 \mathrm{~m}$. Sedimentary structures include trough cross-beds, ripple cross-laminae, and horizontal laminae. Soft-sediment deformation structures are present locally. Transported calamites and small unidentifiable plant fragments are ubiquitous; in-situ calamites and carbonized roots are present in the upper portions of some bodies.

Table 2. Summary of channel body types in the Springhill Mines Formation.

\begin{tabular}{|c|c|c|c|c|c|c|}
\hline Channel Type & $\begin{array}{l}\text { Number and } \\
\text { location }(m) \text { of } \\
\text { occurrences }\end{array}$ & Thickness & W:T Ratio & Internal Organization & Grain Size & Sedimentary Structures and Fossils \\
\hline Fixed & $\begin{array}{c}8 \text { occurrences } \\
25.8 \mathrm{~m}, 42.7 \mathrm{~m} \\
47.5 \mathrm{~m}, 238.5 \mathrm{~m} \\
306 \mathrm{~m}, 323 \mathrm{~m} \\
541.6 \mathrm{~m}, 552.5 \mathrm{~m}\end{array}$ & $\begin{array}{l}3.3 \text { to } 16 \mathrm{~m} \\
\text { (8.3 m avg.) }\end{array}$ & $\begin{array}{c}\text { True: } \\
64.5 \mathrm{~m}=4.7 \\
323 \mathrm{~m}=21.6 \\
\text { Minimum: } \\
4.0-31.5 \\
(15.7 \text { avg. })\end{array}$ & $\begin{array}{l}\text { Single storey bodies with a basal fifth- } \\
\text { order surface. Some have } \\
\text { subhorizontal, fourth-order erosion } \\
\text { surfaces that either onlap or parallel } \\
\text { channel margins. Minimal lateral } \\
\text { migration. Grain size and } \\
\text { sedimentary structures fine upward. }\end{array}$ & $\begin{array}{l}\text { Very-fine- to fine- } \\
\text { grained sandstone with } \\
\text { local mudstone and } \\
\text { siltstone }\end{array}$ & $\begin{array}{l}\text { Trough cross-beds, ripple cross-laminae, } \\
\text { horizontal laminae, intraformational lags with } \\
\text { mud chip rip-up clasts and flattened siderite } \\
\text { nodules. Transported fossils include small } \\
\text { unidentifiable plant fragments, calamites, } \\
\text { lycopsid bark. In-situ calamites and carbonized } \\
\text { roots near the top of some bodies. }\end{array}$ \\
\hline Sheet & $\begin{array}{c}4 \text { occurrences } \\
386.5 \mathrm{~m}, 407.5 \mathrm{~m}, \\
434.6 \mathrm{~m}, 449.2 \mathrm{~m}\end{array}$ & $\begin{array}{l}4.5 \text { to } 17.8 \mathrm{~m} \\
(10 \mathrm{~m} \text { avg.) }\end{array}$ & $\begin{array}{l}\text { Minimum: } \\
19.3-71.3 \\
\text { (38.4 avg.) }\end{array}$ & $\begin{array}{l}\text { Multistorey bodies with a basal sixth- } \\
\text { order surface. Numerous, cross- } \\
\text { cutting fourth- and fifth-order } \\
\text { surfaces result in a chaotic internal } \\
\text { architecture. }\end{array}$ & $\begin{array}{l}\text { Fine-grained sandstone } \\
\text { with medium-grained } \\
\text { sandstone at } 466 \mathrm{~m} \text {. Rare } \\
\text { mudstone. }\end{array}$ & $\begin{array}{l}\text { Trough cross-beds, shallow scours, low-angle } \\
\text { laminae, ripple cross-laminae, and faintly } \\
\text { laminated intervals. Soft sediment deformation } \\
\text { structures present locally. Transported fossils } \\
\text { include cordaite logs, calamites and } \\
\text { unidentifiable plant fragments. Charcoal, } \\
\text { carbonized roots and an in-situ lycopsid were } \\
\text { present at } 386.5 \mathrm{~m} \text {. }\end{array}$ \\
\hline Meandering & $\begin{array}{c}8 \text { occurrences } \\
20.9 \mathrm{~m}, 175.5 \mathrm{~m} \\
526 \mathrm{~m}, 601 \mathrm{~m} \\
619 \mathrm{~m}, 637 \mathrm{~m} \\
687.5 \mathrm{~m}, 691 \mathrm{~m}\end{array}$ & $\begin{array}{c}2.8 \text { to } 10.3 \mathrm{~m} \\
\text { (6.7 } \mathrm{m} \text { avg.) }\end{array}$ & $\begin{array}{l}\text { Minimum: } \\
10.7-58.6 \\
\text { (37.0 avg.) }\end{array}$ & $\begin{array}{l}\text { Generally single storey bodies with a } \\
\text { basal fifth-order surface. } 526 \mathrm{~m} \text { has } \\
\text { two storeys. Abundant lateral } \\
\text { accretion deposits. Intraformational } \\
\text { conglomerates line many internal } \\
\text { erosion surfaces. }\end{array}$ & $\begin{array}{l}\text { Local mudstone and } \\
\text { siltstone; very-fine, fine- } \\
\text { and medium-grained } \\
\text { sandstone. Coarse- } \\
\text { grained sandstone locally. }\end{array}$ & $\begin{array}{l}\text { Trough cross-beds, ripple cross-laminae, } \\
\text { horizontal laminae, and massive to faintly } \\
\text { laminated beds. Soft-sediment deformaiton } \\
\text { structures locally. Transported plant fossils } \\
\text { include calamites, unidentifiable small plant } \\
\text { fragments, coalified lycopsid logs ( } 175.5 \mathrm{~m}) \text {, and } \\
\text { large permineralized cordaite logs ( } 175.5 \mathrm{~m} \text { and } \\
637 \mathrm{~m}) \text {. Kouphichnium, Diplichnites cuithensis, } \\
\text { and tetrapod trackways locally. }\end{array}$ \\
\hline
\end{tabular}




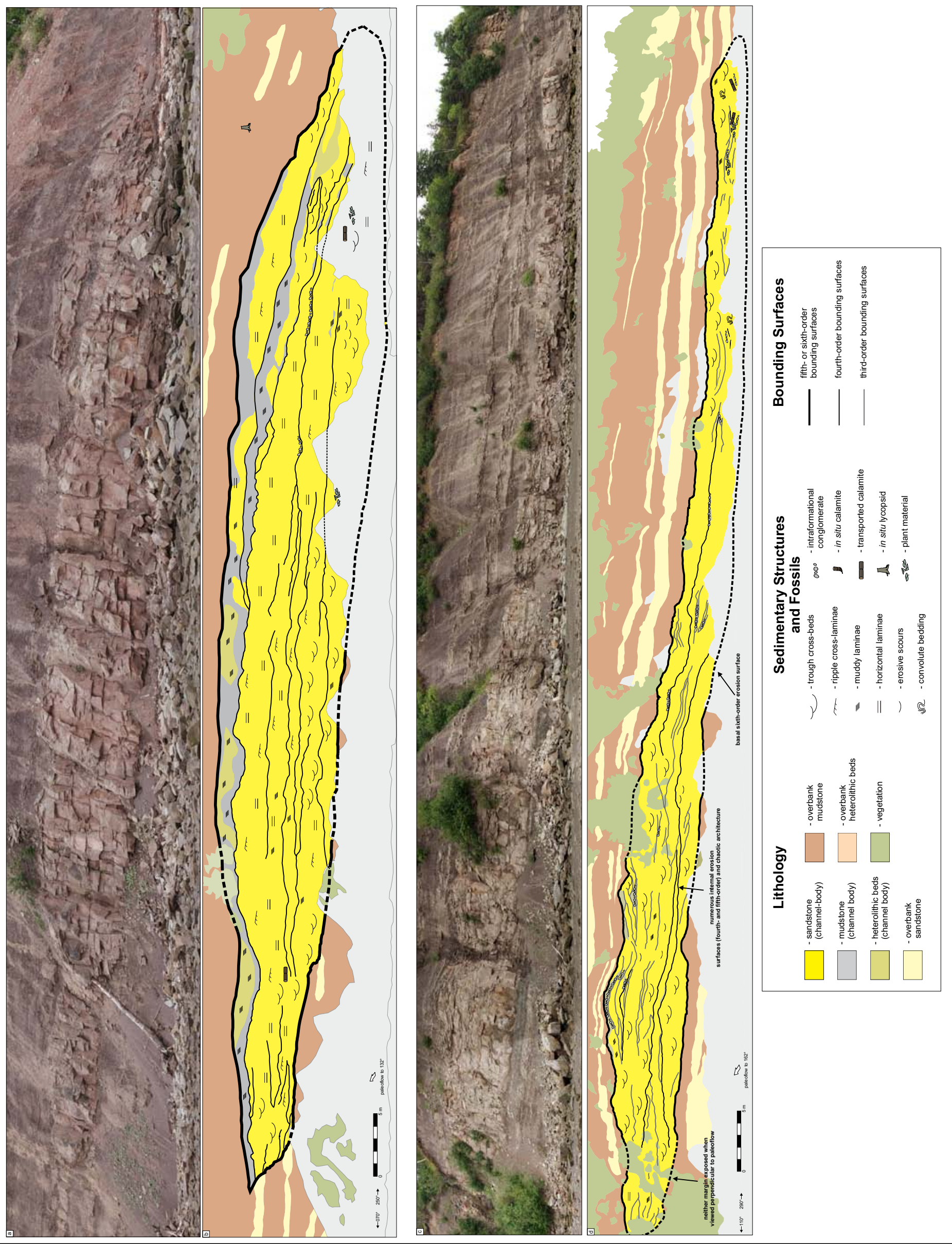




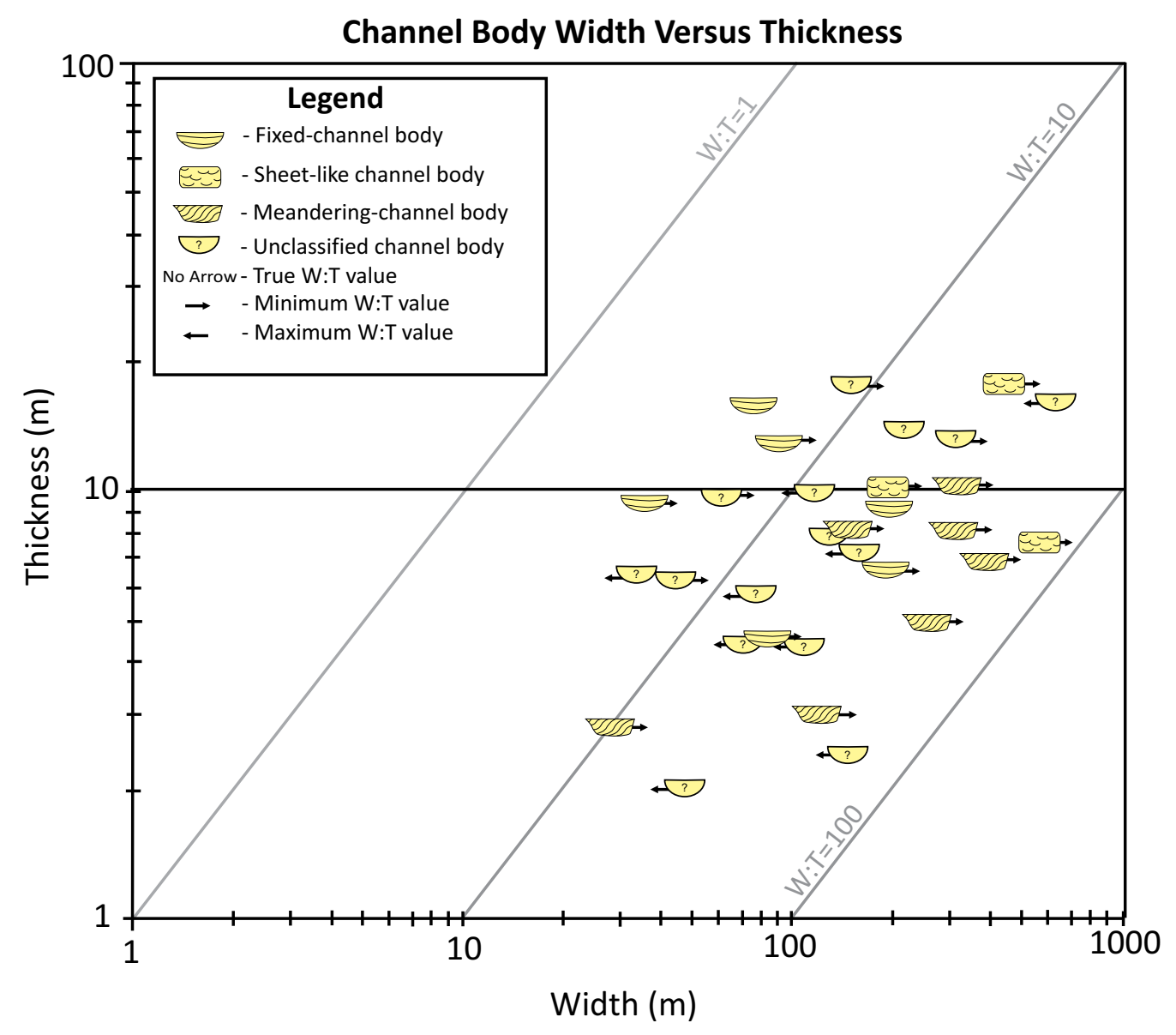

Figure 9. Plot showing width:thickness ratios for the different types of channel bodies present in the Springhill Mines Formation. True widths are reported where paleoflow data was available and both margins of the body were exposed. Maximum widths are reported if no paleoflow data is available but both margins are exposed; minimum widths are reported if one or both of the channel margins extends beyond the outcrop belt.

\section{Interpretation}

Fixed-channel bodies are typically single storey with low W:T ratios and a ribbon-like morphology. The geometry of the channel body roughly approximates the depth of the active channel (3-16 m deep; avg. width:depth ratio of 15). Ubiquitous trough cross-beds are organized into sandy and downstream-accreting barforms. Channels appear to have a simple cut-and-fill history with limited lateral migration. Thin abandoned-channel fills at the top of some bodies record suspension deposition and final abandonment of the channel. This fluvial style is particularly abundant below 333 $\mathrm{m}$ in the measured section.

Although multiple channels were not observed at the same stratigraphic level, we agree with Rust et al.'s (1984) interpretation that the geometry and architecture of these channel bodies is consistent with deposition in an anastomosed river system (Makaske 2001). Specifically, the presence of a well-vegetated floodplain, levees, organicrich deposits, and abundant splays suggests that this fluvial system resembled Nanson and Knighton's (1996) Type 1B organo-clastic fluvial system. These bodies are similar to ancient anastomosed river deposits in the Joggins Formation (Falcon-Lang et al. 2004; Rygel and Gibling 2006), St. Mary's River Formation (Nadon 1994), and Willwood Formation (Kraus and Gwinn 1997), as well as modern anastomosed river systems in Canada and Australia (Smith and Putnam 1980; Gibling et al. 1998; Smith and Pérez-Arlucea 2004).

Figure 8. (previous page) (a, b) Photomosaic and interpretive tracing of the fixed-channel body at $306 \mathrm{~m}$. Note the relatively narrow geometry (image shows almost the entire width of the body), lack of lateral accretion deposits, singlestorey architecture, and largely sandy fill with cross-beds and ripple cross-laminae. (c, d) Photomosaic and interpretive tracing of the sheet-like channel body at $386 \mathrm{~m}$. Note the width of the body (neither margin is exposed), abundance of low-angle erosion surfaces and chaotic architecture, and sandy fill with cross-beds and ripple cross-laminae. 


\section{Sheet-like Channel Bodies}

\section{Description}

The four sheet-like channel bodies in the Springhill Mines Formation all occur in the WDFA between $376 \mathrm{~m}$ and $449.2 \mathrm{~m}$ (Figs $8 \mathrm{c}, \mathrm{d}$ ). Thicknesses range from $4.5 \mathrm{~m}$ to $17.8 \mathrm{~m}$ (10 m avg.). Minimum W:T ratios range from 19.3 to 71 (38 avg.; Fig. 9). Channel fills are bounded by sixthorder surfaces; internally they have numerous cross-cutting, fourth- and fifth-order erosional surfaces. These internal erosional surfaces are extensive and give the channel bodies their distinctive chaotic, multistorey architecture. Erosion surfaces are lined with intraformational conglomerate; a few transported caliche nodules were present in the channel body at $407.5 \mathrm{~m}$. Sheet-channel bodies are composed of fine-grained sandstone organized into trough cross-beds, shallow scours, low-angle laminae, ripple cross-laminae, and massive to faintly laminated intervals. Intervals of mediumgrained sandstone are present in the body at $449.2 \mathrm{~m}$. Thin muddy lenses and soft-sediment deformation structures are common near the tops of these channel bodies. Fossils include transported cordaitalean logs $(386.5 \mathrm{~m}, 434.6$ m, and 449.2 m; Fig. 10a), calamite fragments and small, unidentifiable plant fragments. Fossil charcoal, carbonized roots, and in-situ lycopsids were present near the top of the channel body at $386.5 \mathrm{~m}$. The channel body at 407.5 $\mathrm{m}$ had weakly developed calcareous nodules developed in sandstones near the top (Fig. 10b); it was unclear whether these nodules were soil features (caliche) or diagenetic features.

\section{Interpretation}

Sheet-channel bodies probably had high W:T ratios (probably $>100$ ) and a broad planar form. Internally, these bodies are filled with trough cross-beds organized into sandy and downstream-accreting macroforms. Channel margins are not exposed, but abundant internal erosion surfaces and low-angle laminae suggest that fast, erosive, poorly-channelized flows were present within the confines of the river. These deposits, particularly the large channel body at $386.5 \mathrm{~m}$, are comparable with Miall's (2006) shallow, perennial, sand-bed braided river facies model and may have formed in association with rivers similar to the lower Niobrara or South Saskatchewan Rivers (Cant and Walker 1978; Ethridge et al. 1999; Skelly et al. 2003). These bodies are similar to ancient examples described from the Solling Formation (Olsen 1988) and the multistory channel body from $581 \mathrm{~m}$ in the underlying Joggins Formation (Rygel and Gibling 2006).

\section{Meandering-Channel Bodies}

\section{Description}

Eight meandering-channel bodies are present in the Springhill Mines Formation (Fig. 11), all in the WDFA. A relatively thin ( $2.8 \mathrm{~m}$ thick) body is present in the cliffs at $20.9 \mathrm{~m}$ and a thicker one is present at $175.5 \mathrm{~m}$ (MacCarrons River); the other six occur above $526 \mathrm{~m}$. Laterally equivalent and immediately overlying strata associated with the MacCarrons River channel body are not exposed, and the assignment to the WDFA is provisional. Channels have erosional bases defined by a fifth-order surface. Thicknesses range from 2.8 to $10.3 \mathrm{~m}$ (6.7 m average), and minimum $\mathrm{W}: \mathrm{T}$ values range from 10.7 to 58.6 (37.0 avg.). The channel body at $526 \mathrm{~m}$ is composed of two amalgamated storeys (Fig. 11c, d). The bodies at $687.5 \mathrm{~m}$ and $691 \mathrm{~m}$ are stacked atop one another but are not fully amalgamated and so are described separately. All other meandering-channel bodies consist of a single storey. Minor internal erosion surfaces are inclined perpendicular to paleoflow direction and are lined with intraformational conglomerates composed of mud-chip rip-up clasts, flattened siderite nodules, and coalified logs. Transported calcareous nodules were present in the channel body at $637 \mathrm{~m}$. Internal surfaces separate sets of inclined heterolithic stratification (IHS). The upper portions of IHS sets are composed of mudrock and fine-grained sandstone that grade into fine- to medium-grained sandstone laterally. Common sedimentary structures include trough crossbeds, ripple cross-laminae, horizontal laminae, and massive to faintly laminated beds. The channel bodies at $601 \mathrm{~m}$ and $636 \mathrm{~m}$ have abundant soft-sediment deformation structures. Transported plant fossils include calamites, unidentifiable small plant fragments, coalified lycopsid logs $(175.5 \mathrm{~m})$, and large permineralized cordaitalean logs $(175.5 \mathrm{~m}$ and $637 \mathrm{~m})$. The trace fossils Kouphichnium and Diplichnites cuithensis were observed in channel bodies at $175.5 \mathrm{~m}$ and $526 \mathrm{~m}$ (Figs. $10 \mathrm{c}, \mathrm{d})$. A similar trace-fossil assemblage was observed in an unclassified channel body at $106.5 \mathrm{~m}$. A tetrapod trackway at $175.5 \mathrm{~m}$ occurs on the same surface as, and runs parallel to, a Diplichnites cuithensis.

\section{Interpretation}

These channel bodies are interpreted as the deposits of a meandering fluvial system because they are filled with lateral accretion barforms and have relatively high minimum W:T ratios. The bodies are largely single storey, and the active channels were generally 3 to $10 \mathrm{~m}$ deep. The presence of IHS records fluctuations in flow strength allowed for the transport and deposition of both sandy bedload and muddy suspended load. The channel body at $175.5 \mathrm{~m}$ contains permineralized cordaitalean logs, which Falcon-Lang and 

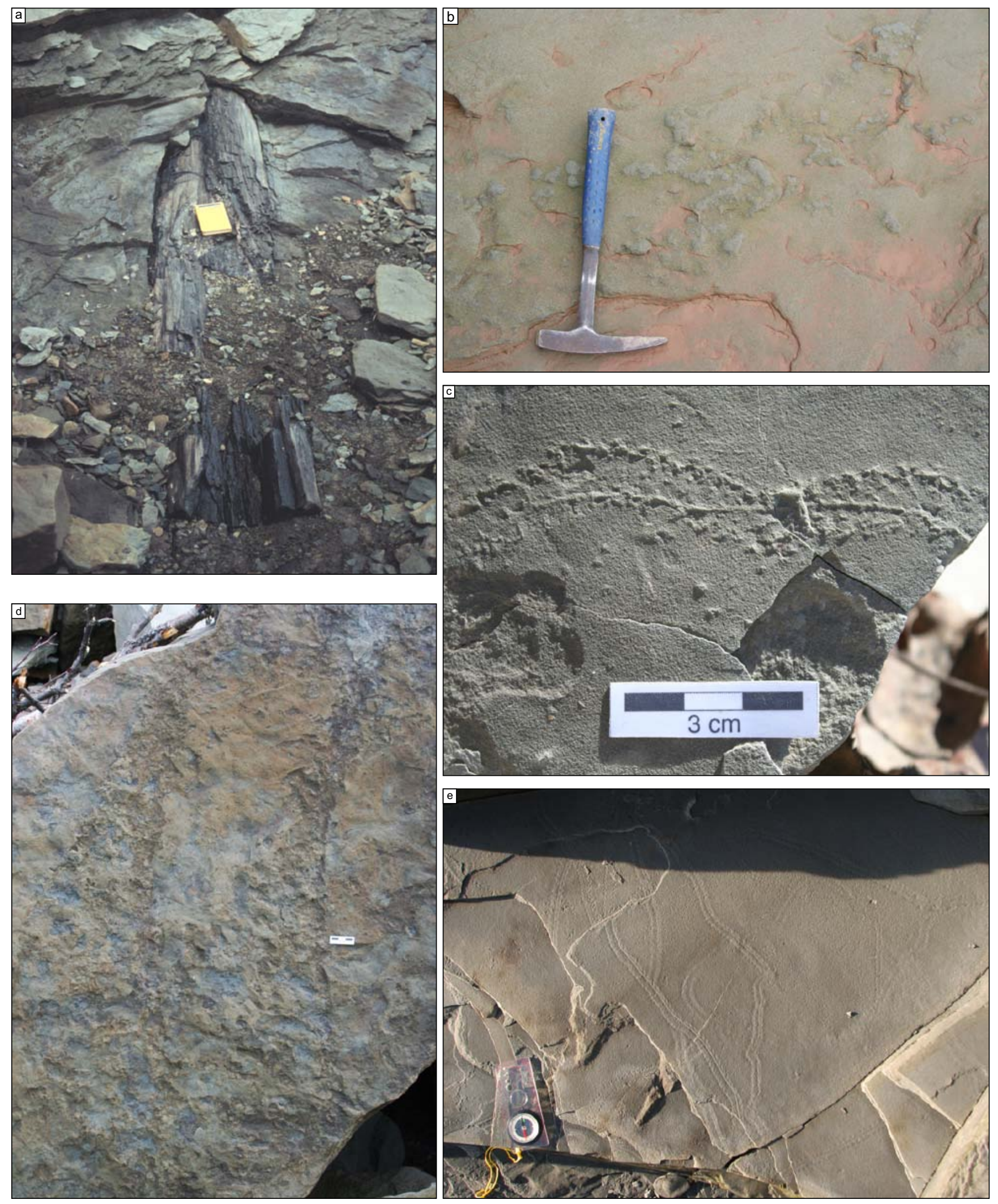

Figure 10. (a) Permineralized cordaitalean log in sheet-like channel body at $434.6 \mathrm{~m}$. (b) Calcareous nodule in meandering-channel body at $628 \mathrm{~m}$. (c) Kouphichnium from talus at the base of meandering-channel body at $526 \mathrm{~m}$ (NSM014GF.015.999). (d) Diplichnites cuithensis from talus at the base of the meandering-channel body at $526 \mathrm{~m}$. (e) Kouphichnium from channel body at $106.5 \mathrm{~m}$. 


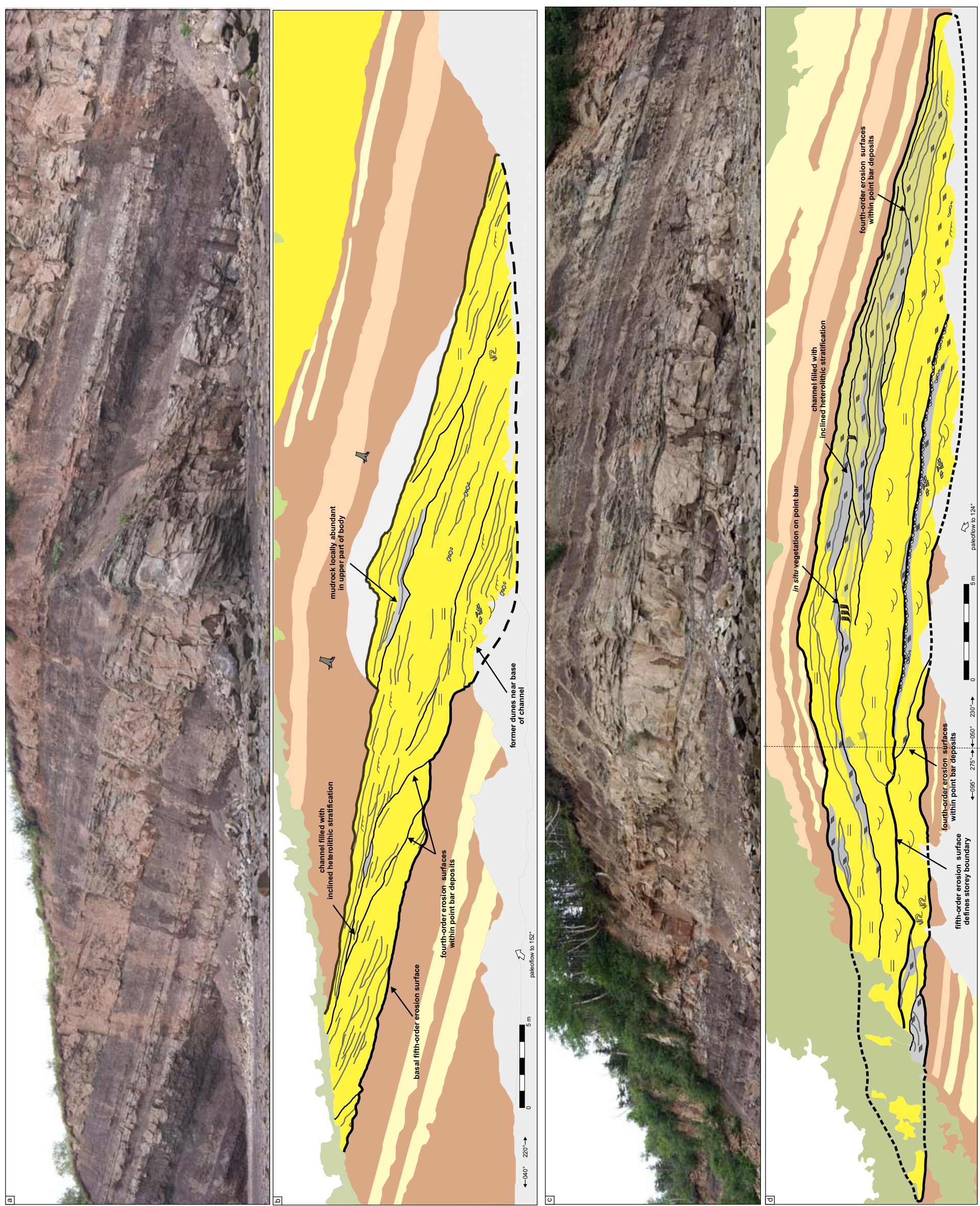


Scott (2000) interpreted as having grown on the adjacent uplands and subsequently transported downstream. These channel bodies are comparable with ancient meandering fluvial systems described from the Joggins Formation (Rygel and Gibling 2006), Clear Fork Group (Edwards et al. 1983), Scalby Formation (Alexander 1992), and Morien Group (Gibling and Rust 1987).

The presence of Kouphichnium and Diplichnites cuithensis from channel bodies at 106.5, 175.5, and $526 \mathrm{~m}$ is the subject of ongoing research (Stimson and MacRae 2010) and provides significant insight into the paleoecology and paleogeography of the Springhill Mines Formation. A growing body of evidence suggests Kouphichnium is most commonly found in strata deposited near the shoreline, where marginal-marine or brackish waters transitioned into wetlands (Archer et al. 1995; Z. Prescott, personal communication, 2013). Additional occurrences of Kouphichnium have also been described from inland exposures of this unit near Springhill (Calder 1994). The presence of Kouphichnium within redbed-channel bodies suggests that these fluvial deposits were deposited close to the coast and were, at least periodically, in communication with marine-influenced waters. The presence of Diplichnites within the same channel bodies records terrestrial myriapods traversing exposed bar surfaces (Stimson and MacRae 2010; Z. Prescott, personal communication, 2013).

\section{DISCUSSION}

\section{Paleoclimate}

Aside from histosols (peat), the coastal exposure of the Springhill Mines Formation does not contain any well-developed paleosols that can be used to reconstruct paleoclimate from field-based observations. Despite the paucity of obvious paleoclimate indicators, some interpretations can be made by considering this unit in its regional context. Annual precipitation during deposition of the formation (both PDFA and WDFA) most likely fell between 1300 and $2500 \mathrm{~mm} / \mathrm{yr}$. This range reflects precipitation amounts where rheotrophic mires could expand to include inland terrestrial surfaces; beyond 2500 $\mathrm{mm} / \mathrm{yr}$, mires can become independent of groundwater and develop into ombrotrophic forms (Retallack 2001). Broadly speaking, the conditions recorded by the Springhill Mines Formation may have been similar to those of the modern Mississippi Delta (1110 to $1700 \mathrm{~mm}$ of precipitation/yr;
Scott et al. 2000), where the difference between the poorly drained (peat-accumulating) and well-drained (non-peat accumulating) swamps reflects local drainage conditions (Roberts et al. 1983). Under these conditions, well-drained swamps have similar organic production to poorly drained swamps and may be underwater for several months of the year, but the presence of oxidizing conditions for part of the year results in the nearly complete destruction of plant material and the formation of iron-oxide nodules (sensu Stevenson 1969).

Studies of paleosols (Smith 1991), plant fossils (Falcon-Lang 1999; Falcon-Lang and Scott 2000; Utting et al. 2010), and fluvial architecture (Allen et al. 2013) in this unit suggest only modest seasonality. Although not present in the Springhill Mines Formation, calcretes are present in basin-margin redbeds of the broadly coeval Tynemouth Creek and New Glasgow formations (Plint and van de Poll 1982; Chandler 1998), suggesting that, at specific times and locations, conditions were suitable for carbonate accumulation if soils were given sufficient time to develop. Such conditions would be more likely in these proximal units, which likely experienced better drainage and slower sedimentation rates (Platt and Keller 1992). The development of crude cyclicity in the Springhill Mines Formation is consistent with astronomically forced cycles in the Milankovitch band (Calder 1994). Increased seasonality may have heralded the cessation of peat accumulation and increased sedimentation (Cecil 1990; Calder 1994; Allen et al. 2013). The deposition of sheet-like channel bodies may record relatively short-lived phases of more pronounced seasonality during glacial maxima (Tandon and Gibling 1994).

\section{Stratigraphic Architecture}

The interval described in this paper can be classified using the threefold facies scheme developed for the underlying Joggins Formation (Davies and Gibling 2003; Davies et al. 2005). Joggins Formation cyclicity consists of alternations between OWFA deposits formed during widespread transgressions, PDFA deposits formed as coastal wetlands or low-lying portions of the floodplain, and WDFA deposits formed as aggradation of the alluvial surface allowed for regular subaerial exposure of sediments. At times, these environments may have been laterally equivalent to each other (Allen et al. 2013) and major shifts in the distribution of facies belts were driven by a combination of glacioeustasy,

Figure 11. (previous page) Photomosaics and interpretive tracings of meandering-channel bodies. The tracing uses the same legend as in Fig. 8. (a, b) Single-storey meandering-channel body at $601 \mathrm{~m}$. Note the presence of southwest-dipping erosion surfaces that define reactivation surfaces within point-bar deposits. (c, d) Multistorey meandering-channel body at $526 \mathrm{~m}$. Note heterolithic fill and northeast-dipping erosion surfaces within point-bar deposits. Slabs of sandstone with Kouphichnium and Diplichnites (Figs. $10 \mathrm{c}, \mathrm{d}$ ) were found at the base of this channel body. 
rapid subsidence, and sediment supply (Rygel et al. 2008; Gibling and Rygel 2008).

The single occurrence of OWFA strata in the uppermost Joggins Formation (915.5-932.4 m) records the aftermath of the final flooding event of sufficient magnitude to cause deposition of organic-rich limestones, laminated mudrocks, and sharp-based sandstones in this part of the basin. As salt withdrawal progressively slowed during deposition of the Springhill Mines Formation (Waldron et al. 2013), sediment supply would have been able to outpace accommodation, which would have resulted in shallower water (or complete exposure) during flooding events and a more basinward shoreline position. Thus, the alternations between PDFA and WDFA deposits in the Springhill Mines Formation may record the updip expression of glacioeustatically driven cyclicity in a rapidly subsiding basin, a situation nearly identical to that envisaged for the underlying Joggins Formation (Davies and Gibling 2003; Gibling and Rygel 2008). The progressive increase in WDFA deposits through the formation records continued aggradation of the alluvial surface as the wedge of sediment shed from the Caledonia Highlands prograded into the basin (Rust et al. 1984).

\section{Changes in Fluvial Style}

Channel bodies in the Springhill Mines Formation record a progressive shift from predominantly fixed(anastomosed-) channel bodies below $376 \mathrm{~m}$, to a cluster of sheet-like channel bodies between 376 and $449 \mathrm{~m}$, to predominantly meandering-channel bodies above $449 \mathrm{~m}$. This change is accompanied by a progressive increase in the abundance of WDFA deposits.

Of the two meandering-channel bodies present below $376 \mathrm{~m}$, one (at $20.9 \mathrm{~m}$ ) is a minor tributary or distributary channel and the other (MacCarrons River channel body at $175.5 \mathrm{~m}$ ) is a 6.9-m-thick channel body that likely represents an average sized, through-going channel on the Springhill Mines Formation floodplain. The presence of a meandering channel at this position in the section may record either paleogeomorphic variability in the drainage network (Rygel and Gibling 2006) or a brief incursion of the upland fluvial style (meandering-river deposits with cordaitalean logs) that are common in overlying strata.

The clustering of sheet-like channel bodies in WDFA deposits between 376 and $449 \mathrm{~m}$, combined with an increase in the abundance of transported cordaitalean logs and fossil charcoal (channel body at $386 \mathrm{~m}$ ), suggests that these channel bodies may represent a period of increased sediment input and flashy flow, perhaps in response to a short-term change in seasonality or destabilization of the landscape by fire (Falcon-Lang 1999).

The meandering-channel bodies in redbeds above 449 $\mathrm{m}$ represent a change in fluvial style that existed in more proximal areas of the floodplain, where steeper gradients may have existed (Rust et al. 1984). Although we agree with the patterns recognized by Rust et al. (1984), we interpret the transition as occurring at $449 \mathrm{~m}$ in the Springhill Mines Formation, which is considerably lower than their placement at $70 \mathrm{~m}$ above the Springhill Mines-Ragged Reef contact. The presence of anabranching channels in downdip areas and meandering channels in updip areas may maximize the fluvial system's ability to transport in low-gradient areas (Nanson and Knighton 1996). Törnqvist et al. (1993) described similar longitudinal changes in the Rhine-Meuse Delta, where anastomosed channels are most common in low-gradient coastal areas and meandering channels are more common in updip, steeper-gradient areas.

\section{CONCLUSIONS}

The base of our measured section consists of $16.9 \mathrm{~m}$ of dark laminated mudrocks and sharp-based sandstones that are assigned to the open water facies association, a hallmark of the Joggins Formation. Given the lithological similarity to the underlying Joggins Formation and dissimilarity to the overlying Springhill Mines Formation, we reassign this interval to the top of the Joggins Formation (915.5 to 932.4 $\mathrm{m})$. We redefine the Joggins Formation as a coal-bearing interval with bivalve-bearing limestones and interbedded dark shales and sharp-based sandstones assignable to the OWFA of Davies et al. (2005), which allows for a mappable lithostratigraphic definition that also includes all strata deposited as a direct consequence of the widespread flooding events that inundated the basin with brackish waters.

Strata in the overlying 697-m-thick Springhill Mines Formation can be considered in terms of poorly drained and well drained facies associations (PDFA and WDFA respectively) as described from the underlying Joggins Formation (Davies et al. 2005). PDFA wetland deposits with thin coals and forested horizons are particularly common in the lower part of the formation. WDFA deposits contain reddish-brown mudrocks with immature paleosols and scattered occurrences of in-situ vegetation. These redbeds do not contain well-developed paleosols or obvious indicators of pronounced seasonality. Although OWFA deposits are absent, the presence of mangrove-like cordaitaleans and Kouphichnium in PDFA and WDFA deposits provides a cryptic record of ongoing transgressive events throughout deposition of the Springhill Mines Formation.

Alternations between PDFA and WDFA strata may record the updip expression of glacioeustatically driven cyclicity in a rapidly subsiding basin. The upward increase in the abundance of redbeds records aggradation of the alluvial surface as sediment derived from the Caledonia Highlands prograded into central parts of the basin. Aggradation of the alluvial surface may have been enhanced by decreasing halokinetic subsidence through deposition of the Springhill Mines Formation. 
These changes in depositional environment are accompanied by a transition from fixed channels in the lower part of the section $(<376 \mathrm{~m})$, to an interval dominated by sheet-like channel bodies (376-449 $\mathrm{m}$ ), and then into meandering-channel bodies ( $>449 \mathrm{~m}$ ). The transition from fixed to meandering-channel bodies records a longitudinal change from an anastomosed system in low-gradient coastal areas to a meandering system in more updip areas. The cluster of erosive, sheet-like channel bodies may record a pulse of sediment delivered in response to short-term climate change.

Although the coastal exposure of the Springhill Mines Formation makes up a significant portion of the Joggins Fossil Cliffs UNESCO World Heritage Site, this paper represents the first comprehensive description of these strata. The detailed measured section, outcrop map, and preliminary description and interpretation of these strata provides a framework for future sedimentological and paleontological studies of this iconic exposure of Pennsylvanian strata.

\section{ACKNOWLEDGEMENTS}

M. Rygel acknowledges the donors of the American Chemical Society Petroleum Research Fund (PRF Grant \#47967-GB8) and a sabbatical granted by the State University of New York, College at Potsdam. K. Ashley and E. Sheldon were supported by Kilmer Undergraduate Research Apprenticeships and the Neal R. O'Brien Scholarship (SUNY Potsdam). We thank the Joggins Fossil Institute for their assistance at many points and for supporting our applications for Heritage Research Permits. Brian Hebert, Andrew MacRae, Don Reid, and Len Reid provided supplementary information about the location and identification of some of the fossils identified in Appendix 3. Initial comments by Andrew MacRae, thoughtful reviews by Melissa Grey and David Keighley, and editorial guidance by Rob Fensome greatly improved this manuscript.

\section{REFERENCES}

Alexander, J. 1992. Nature and origin of a laterally extensive alluvial sandstone body in the Middle Jurassic Scalby Formation. Journal of the Geological Society, 149, pp. 431-441. http://dx.doi.org/10.1144/gsigs.149.3.0431

Allen, J., Fielding, C.R., Gibling, M.R., and Rygel, M.C. 2011. Fluvial response to paleo-equatorial climate fluctuations during the late Paleozoic ice age. Geological Society of America Bulletin, 128, pp. 1524-1538. http://dx.doi. org/10.1130/B30314.1

Allen, J.P., Fielding, C.R., Rygel, M.C., and Gibling, M.R. 2013. Deconvolving signals of tectonic and climatic controls from continental basins: an example from the late Palaeozoic Cumberland Basin, Nova Scotia. Journal of Sedimentary Research, 83, pp. 847-872. http://dx.doi. org/10.2110/jsr.2013.58

Archer, A.W., Calder, J.H., Gibling, M.R., Naylor, R.D., Reid, D.R., and Wightman, W.G. 1995. Invertebrate trace fossils and agglutinated foraminifera as indicators of marine influence within the classic Carboniferous section at Joggins, Nova Scotia, Canada. Canadian Journal of Earth Sciences, 32, pp. 2027-2039. http://dx.doi.org/10.1139/ e95-156

Bell, W.A. 1912. Joggins Carboniferous section of Nova Scotia. Geological Survey of Canada, Summary Report for 1911, pp. 328-333.

Bell, W.A. 1914. Joggins Carboniferous section, Nova Scotia. Geological Survey of Canada, Summary Report for 1912, pp. 360-371.

Bell, W.A. 1943. Carboniferous rocks and fossil floras of northern Nova Scotia. Geological Survey of Canada, Memoir 238, 277 p.

Belt,E.S. 1964. Revision of Nova Scotia middle Carboniferous units. American Journal of Science, 262, pp. 653-673. http://dx.doi.org/10.2475/ajs.262.5.653

Beuthin, J.D. and Blake, B.M. 2002. Scrutiny of a global climate model for Upper Mississippian depositional sequences in the central Appalachian foreland basin, USA. Journal of Geology, 110, pp. 739-747. http://dx.doi. org/10.1086/342867

Boon, J. and Calder, J.H. 2007. Nomination of the Joggins Fossil Cliffs for inscription on the World Heritage List. Amherst, Nova Scotia, Cumberland Regional Economic Development Association, 129 p. http://whc.unesco.org/ uploads/nominations/1285.pdf

Brand, U. 1994. Continental hydrology and climatology of the Carboniferous Joggins Formation (lower Cumberland Group) at Joggins, Nova Scotia: evidence from the geochemistry of bivalves. Palaeogeography, Palaeoclimatology, Palaeoecology, 106, pp. 307-321. http://dx.doi.org/10.1016/0031-0182(94)90016-7

Browne, G.H. and Plint, A.G. 1994. Alternating braidplain and lacustrine deposition in a strike-slip setting: the Pennsylvanian Boss Point Formation of the Cumberland Basin, Maritime Canada. Journal of Sedimentary Research, B64, pp. 40-59.

Calder, J.H. 1991. Controls on Westphalian peat accumulation: the Springhill Coalfield. Unpublished $\mathrm{PhD}$ thesis, Dalhousie University, Halifax, Nova Scotia, Canada, $310 \mathrm{p}$.

Calder, J.H. 1993. The evolution of a ground-waterinfluenced (Westphalian B) peat-forming ecosystem in a piedmont setting: the No. 3 seam, Springhill coalfield, Cumberland Basin, Nova Scotia. In Modern and ancient coal-forming environments. Edited by J.C. Cobb and C.B. Cecil. Geological Society of America, Special Paper 286, pp. 153-180. http://dx.doi.org/10.1130/SPE286-p153 
Calder, J.H. 1994. The impact of climate change, tectonism and hydrology on the formation of Carboniferous tropical intermontane mires: the Springhill coalfield, Cumberland Basin, Nova Scotia. Palaeogeography, Palaeoclimatology, Palaeoecology, 106, pp. 323-351. http://dx.doi. org/10.1016/0031-0182(94)90017-5

Calder, J.H. 1995. Geological map of the Springhill Coalfield, Cumberland County, Nova Scotia [parts of 21H/09A and D]. Nova Scotia Department of Natural Resources Map ME 1995-1, scale 1:10 000.

Calder, J.H. 1998. The Carboniferous evolution of Nova Scotia. In Lyell, the past is the key to the present. Edited by D.J. Blundell and A.C. Scott. Geological Society, Special Publication 143, pp. 261-302.

Calder, J.H. 2012. The Joggins Fossil Cliffs: Coal Age Galapagos. Halifax, Nova Scotia, Nova Scotia Department of Natural Resources, $96 \mathrm{p}$.

Calder, J.H. and Gibling, M.R. 1994. The Euramerican Coal Province: controls on late Paleozoic peat accumulation. Palaeogeography, Palaeoclimatology, Palaeoecology, 106, pp. 1-21. http://dx.doi.org/10.1016/0031-0182(94)900027

Calder, J.H., Gibling, M.R., and Mukhopadhyay, P.K. 1991. Peat formation on a Westphalian B piedmont setting, Cumberland Basin, Nova Scotia; implications for the maceral-based interpretation of rheotrophic and raised paleomires. Bulletin de la Société Géologique de France, 162, pp. 283-298.

Calder, J.H., Rygel, M.C., Hebert, B.L., and Falcon-Lang, H.J. 2005. Sedimentology and stratigraphy of Pennsylvanian red beds near Joggins, Nova Scotia: the proposed Little River Formation with redefinition of the Joggins Formation. Atlantic Geology, pp. 143-167.

Calder, J.H., Gibling, M.R., Scott, A.C., Davies, S.J., and Hebert, B.L. 2006. Paleoecology and sedimentology of a fossil lycopsid forest succession in the classic Pennsylvanian section at Joggins, Nova Scotia. In Wetlands through time. Edited by S.F. Greb and W.A. DiMichele. Geological Society of America, Special Paper 399, pp. 169-195.

Cant, D.J. and Walker, R.G. 1978. Fluvial processes and facies sequences in the sandy braided South Saskatchewan River, Canada. Sedimentology, 25, pp. 625-648. http:// dx.doi.org/10.1111/j.1365-3091.1978.tb00323.x

Carpenter, D.K., Falcon-Lang, H.J., Grey, M., and Benton, M.J. 2013. Fish skeletal assemblages from the famous Joggins Fossil Cliffs of Nova Scotia: systematics, paleoecology, and paleoenvironments. Atlantic Geology, 49, pp. 23.

Cecil, C.B. 1990. Paleoclimate controls on stratigraphic repetition of chemical and siliclastic rocks. Geology, 18, pp. 533-536. http://dx.doi.org/10.1130/00917613(1990)018<0533:PCOSRO > 2.3.CO;2

Chandler, F.W. 1998. Geology of and climatic indicators in the Westphalian A New Glasgow Formation, Nova Scotia, Canada: implications for the genesis of coal and of sandstone-hosted lead deposits. Atlantic Geology, 34, pp. 39-56.

Copeland, M.J. 1959. Coalfields, West half Cumberland County, Nova Scotia, Geological Survey of Canada, Memoir 298, 89 p.

Cotton W., Hunt, A.P., and Cotton, J. 1995. Paleozoic vertebrate tracks sites in eastern North America. In Early Permian footprints and facies. Edited by S.G. Lucas.and A.B. Heckett. New Mexico Museum of Natural History Bulletin, 6, pp. 189-217.

Davies, S.J. and Gibling, M.R. 2003. Architecture of coastal and alluvial deposits in an extensional basin: the Carboniferous Joggins Formation of eastern Canada. Sedimentology, 50, pp. 415-439. http://dx.doi. org/10.1046/j.1365-3091.2003.00553.x

Davies, S.J., Gibling, M.R., Rygel, M.C., Calder, J.H., and Skilliter, D.M. 2005. The Joggins Formation: stratigraphic framework and sedimentological log of the historic fossil cliffs. Atlantic Geology, 41, pp. 115-142.

Davydov, V., Wardlaw, B.R., and Gradstein, F.M. 2004. The Carboniferous Period. In A Geologic time scale 2004. Edited by F.M. Gradstein, J.G. Ogg, and A.G. Smith. Cambridge University Press. New York, pp. 222-248.

Dawson, J. W. 1868. Acadian Geology. The geological structure, organic remains, and mineral resources of Nova Scotia, New Brunswick, and Prince Edward Island. MacMillan, London, 694 p. http://dx.doi.org/10.5962/ bhl.title.38560

Dimitrova, T.K., Cleal, C.J., and Thomas, B.A. 2011. Palynological evidence for Pennsylvanian extra-basinal vegetation in Atlantic Canada. Journal of the Geological Society, 168, pp. 559-569. http://dx.doi.org/10.1144/001676492010-028

Dolby, G. 1991. The palynology of the western Cumberland Basin, Nova Scotia: Halifax, Nova Scotia Department of Mines and Energy, Open File Report, 1991-6, 51 p.

Dolton, G. L. 2006. Pannonian Basin Province, central Europe (Province 4808) - petroleum geology, total petroleum systems, and petroleum resource assessment. U.S. Geological Survey, Bulletin 2204-B, 47 p.

Duff, P.M. and Walton, E.K. 1973. Carboniferous sediments at Joggins, Nova Scotia. In Seventh International Congress on Carboniferous Stratigraphy and Geology, Compte Rendu. Geologisches Landesant Nordrhein-Westphalen. Krefeld, pp. 365-379.

Edwards, M.C., Eriksson, K.A., and Kier, R.S. 1983. Paleochannel geometry and flow patterns determined from exhumed Permian point bars in north-central Texas. Journal of Sedimentary Petrology, 53, pp. 1261-1270.

Ethridge, F.G., Skelly, R.L., and Bristow, C.S. 1999. Avulsion and crevassing in the sandy, braided Niobrara River: complex response to base-level rise and aggradation. In 
Fluvial sedimentology VI. Edited by N.D. Smith and J. Rogers. International Association of Sedimentologists, Special Publication, pp. 179-191.

Falcon-Lang, H.J. 1999. Fire ecology of a Late Carboniferous floodplain, Joggins, Nova Scotia. Journal of the Geological Society, 156, pp. 137-148. http://dx.doi.org/10.1144/ gsjgs.156.1.0137

Falcon-Lang, H.J. 2003. Response of Late Carboniferous tropical vegetation to transgressive-regressive rhythms at Joggins, Nova Scotia. Journal of the Geological Society, 160, pp. 643-648. http://dx.doi.org/10.1144/0016764902-114

Falcon-Lang, H.J. 2005. Small cordaitalean trees in a marine-influenced coastal habitat in the Pennsylvanian Joggins Formation, Nova Scotia. Journal of the Geological Society, 162, pp. 485-500. http://dx.doi.org/10.1144/0016764904-080

Falcon-Lang, H.J. and Scott, A.C. 2000. Upland ecology of some Late Carboniferous cordaitalean trees from Nova Scotia and England. Palaeogeography, Palaeoclimatology, Palaeoecology, 156, pp. 225-242. http://dx.doi. org/10.1016/S0031-0182(99)00142-X

Falcon-Lang, H.J., Rygel, M.C., Gibling, M.R., and Calder, J.H. 2004. An early Pennsylvanian waterhole deposit and its fossil biota in dryland alluvial plain setting, Joggins, Nova Scotia. Journal of the Geological Society, London, 161, pp. 209-222. http://dx.doi.org/10.1144/0016764903-109

Falcon-Lang, H.J., Gibling, M.R., Benton, M.J., Miller, R.F., and Bashforth, A.R. 2010. Diverse tetrapod trackways in the Lower Pennsylvanian Tynemouth Creek Formation, near St. Martins, southern New Brunswick, Canada. Palaeogeography, Palaeoclimatology, Palaeoecology, 296, pp. 1-13. http://dx.doi.org/10.1016/j.palaeo.2010.06.020

Gastaldo, R.A. 1987. Confirmation of Carboniferous clastic swamp communities. Nature, 326, pp. 869-871. http:// dx.doi.org/10.1038/326869a0

Gibling, M.R. 2006. Width and thickness of fluvial channel bodies and valley fills in the geological record: a literature compilation. Journal of Sedimentary Research, 76, pp. 731-770. http://dx.doi.org/10.2110/jsr.2006.060

Gibling, M.R. and Rust, B.R. 1987. Evolution of a mudrich meander belt in the Carboniferous Morien Group, Nova Scotia, Canada. Canadian Society of Petroleum Geologists Bulletin, 35, pp. 24-33.

Gibling, M.R. and Rygel, M.C. 2008. Late Paleozoic cyclic strata of Euramerica: recognition of Gondwanan glacial signatures during periods of thermal subsidence. In Resolving the late Paleozoic Ice Age in time and space. Edited by C.R. Fielding, T.D. Frank, and J.L. Isbell. Geological Society of America, Special Publication 441, pp. 219-233.

Gibling, M.R., Nanson, G.C., and Maroulis, J.C. 1998. Anastomosing river sedimentation in the Channel
Country of central Australia. Sedimentology, 45, pp. 595619. http://dx.doi.org/10.1046/j.1365-3091.1998.00163.x Gibling, M.R., Culshaw, N., Rygel, M.C., and Pascucci, V. 2008. The Maritimes Basin of Atlantic Canada: basin creation and destruction in the collisional zone of Pangea. In The Phanerozoic sedimentary basins of the United States and Canada. Edited by A.D. Miall. Elsevier, Amsterdam, pp. 211-244. http://dx.doi.org/10.1016/ S1874-5997(08)00006-3

Gibling, M.R., Bashforth, A.R., Falcon-Lang, H.J., Allen, J.P., and Fielding, C.R. 2010. Log jams and flood sediment buildup caused channel abandonment and avulsion in the Pennsylvanian of Atlantic Canada. Journal of Sedimentary Research, 80, pp. 268-287. http://dx.doi. org/10.2110/jsr.2010.024

Gradstein, F.M., Ogg, J.G., and Schmitz, M. 2012. The Geologic time scale 2012. Elsevier, Waltham, Massachussetts, 1144 p. (2-volume set)

Grey, M. and Finkel, Z.V. 2011. The Joggins Fossil Cliffs UNESCO World Heritage site: a review of recent research. Atlantic Geology, 47, pp. 185-200. http://dx.doi. org/10.4138/atlgeol.2011.009

Grey, M., Pufahl, P.K., and Aziz, A.A. 2011. Using multiple environmental proxies to determine degree of marine influence and paleogeographical position of the Joggins Fossil Cliffs, UNESCO World Heritage Site. Palaios, 26, pp. 256-263. http://dx.doi.org/10.2110/palo.2010.p10$118 \mathrm{r}$

Hacquebard, P.A. and Donaldson, J.R. 1964. Stratigraphy and palynology of the Upper Carboniferous coal measures in the Cumberland Basin of Nova Scotia. 5th International Congress on Carboniferous Stratigraphy and Geology, Compte Rendu, 3, pp. 1157-1169.

Holbrook, J. 2001. Origin, genetic interrelationships, and stratigraphy over the continuum of fluvial channelform bounding surfaces: an illustration from middle Cretaceous strata, southeastern Colorado. Sedimentary Geology, 144, pp. 179-222. http://dx.doi.org/10.1016/ S0037-0738(01)00118-X

Hower, J.C., Calder, J.H., Eble, C.F., Scott, A.C., Robertson, J.D., and Blanchard, L.J. 2000. Metalliferous coals of the Westphalian A Joggins Formation, Cumberland Basin, Nova Scotia, Canada: petrology, geochemistry, and palynology. International Journal of Coal Geology, 42, pp. 185-206. http://dx.doi.org/10.1016/S01665162(99)00039-7

Howie, R.D. and Barss, M.S. 1975. Upper Paleozoic rocks of the Atlantic Provinces, Gulf of St. Lawrence, and adjacent continental shelf. Geological Survey of Canada, Paper 7430, pp. 35-50.

Hunt, A.P., Lucas, S.G., Calder, J.H., Van Allen, H.E.K., George, E., Gibling, M.R., Hebert, B.L., Mansky, C., and Reid, D.R. 2004. Tetrapod footprints from Nova Scotia: the Rosetta Stone for Carboniferous tetrapod ichnology. 
Geological Society of America Abstracts with Programs, 36, p. 66.

Ielpi, A., Gibling, M.R., Bashforth, A.R., Lally, C., Rygel, M.C., and Al-Silwadi, S. 2014. Role of vegetation in shaping Early Pennsylvanian braided rivers: architecture of the Boss Point Formation, Atlantic Canada. Sedimentology, 61, pp. 1659-1700. http://dx. doi.org/10.1111/sed.12109

Kaplan, S.S. 1980. The sedimentology, coal petrography, and trace element geochemistry of coal-bearing sequences from Joggins, Nova Scotia, Canada, and southeastern Nebraska, USA. Unpublished Ph.D. thesis, University of Pittsburgh, Pittsburgh, Pennsylvania, 304 p.

Kaplan, S.S. and Donahue, J. 1980. Sedimentologic description of part of coal-bearing Carboniferous sequence exposed near Joggins, Nova Scotia. American Association of Petroleum Geologist Bulletin, 64, pp. 730731.

Kaplan, S.S., Donahue, J., Carr, J.D., and Kelter, P.B. 1985. Analysis of the trace-element content of coals from the Carboniferous Cumberland Group, near Joggins, Nova Scotia, Canada. Canadian Journal of Earth Sciences, 22, pp. 626-629.

Keighley, D.G., Calder, J.H., Park, A.F., Pickerill, R.K., Waldron, J.W., Falcon-Lang, H.J., and Benton, M.J. 2008. Discussion on ecology of earliest reptiles inferred from basal Pennsylvanian trackways. Journal of the Geological Society, 165, pp. 983-987. http://dx.doi.org/10.1144/001676492008-045

Kelley, D.G. 1967. Some aspects of Carboniferous stratigraphy and depositional history in the Atlantic Provinces. In Collected papers on geology of the Atlantic Region: Hugh Lilly Memorial Volume. Edited by E.R.W. Neale and H. Williams. Geological Association of Canada, Special Paper 4, pp. 213-228.

Keppie, J.D. 2006. Digital version of Nova Scotia Department of Natural Resources Map ME 2000-1, Geological Map of the Province of Nova Scotia: Halifax, Nova Scotia, Nova Scotia Department of Natural Resources, 1:500,000.

Kraus, M.J. 1999. Paleosols in clastic sedimentary rocks: their geologic applications. Earth Science Reviews, 47, pp. 41-70. http://dx.doi.org/10.1016/S0012-8252(99)00026-4

Kraus, M.J. and Gwinn, B. 1997. Facies and facies architecture of Paleogene floodplain deposits, Willwood Formation, Bighorn Basin, Wyoming, USA. Sedimentary Geology, 114, pp. 33-54. http://dx.doi.org/10.1016/ S0037-0738(97)00083-3

Logan, W.E. 1845. A section of the Nova Scotia coal measures as developed at Joggins on the Bay of Fundy, in descending order, from the neighbourhood of the west Ragged Reef to Minudie, reduced vertical thickness. Appendix W: Geological Survey, Journals of the Legislative Assembly of the Province of Canada, 1844-5, 4, pp. W28-W45.

Lyell, C. 1871. The student's elements of geology. Harper, New York, 640 p. http://dx.doi.org/10.1680/tseog.52581
Machette, M.N. 1985. Calcic soils of the southwestern United States. In Soils and Quaternary geology of the southwestern United States. Edited by D.L. Weide. Geological Society of America, Special Paper 203, pp. 1-21. http://dx.doi.org/10.1130/SPE203-p1

Makaske, B. 2001. Anastomosing rivers: a review of their classification, origin and sedimentary products. Earth Science Reviews, 53, pp. 149-196. http://dx.doi. org/10.1016/S0012-8252(00)00038-6

Martel, A.T. 1987. Seismic stratigraphy and hydrocarbon potential of the strike-slip Sackville sub-basin, New Brunswick. In Sedimentary basins and basin-forming mechanisms. Edited by C. Beaumont and A.J. Tankard. Canadian Society of Petroleum Geologists, Memoir 12, pp. 319-334.

McBride, B.C., Rowan, M.G., and Weimer, P. 1998. The evolution of allochthonous salt systems, northern Green Canyon and Ewing Bank (offshore Lousiana), northern Gulf of Mexico. American Association of Petroleum Geologists Bulletin, 82, pp. 1013-1036.

Miall, A.D. 2006. The geology of fluvial deposits. Berlin, Springer, 582 p. http://dx.doi.org/10.1007/978-3-66203237-4

Nadon, G.C. 1994. The genesis and recognition of anastomosed fluvial deposits: data from the St. Mary River Formation, southwestern Alberta, Canada. Journal of Sedimentary Research, B64, pp. 451-463.

Nance, R.D. 1987. Dextral transpression and Late Carboniferous sedimentation in the Fundy coastal zone of southern New Brunswick. In Sedimentary basins and basin-forming mechanisms. Edited by C. Beaumont and A.J. Tankard. Canadian Society of Petroleum Geologists, Memoir 12, pp. 363-377.

Nanson, G.C. and Knighton, A.D. 1996. Anabranching rivers: their cause, character and classification. Earth Surface Processes and Landforms, 21, pp. 217-239. http://dx.doi. org/10.1002/(SICI) 1096-9837(199603)21:3<217::AIDESP611>3.0.CO;2-U

New Brunswick Department of Natural Resources and Energy. 2000. Bedrock geology of New Brunswick. New Brunswick Department of Natural Resources, Minerals and Energy Division Map NR-1, scale 1:500 000.

Ogg, J. and Lugowski, A. 2014. TSCreator visualization of enhanced Geologic Time Scale 2004 database (Version $6.2 ; 2014)$, http://www.tscreator.org

Olsen, H. 1988. The architecture of a sandy braidedmeandering river system: an example from the Lower Triassic Solling Formation (M. Buntsandstein) in W-Germany. Geologische Rundschau, 77, pp. 797-814. http://dx.doi.org/10.1007/BF01830186

Phillips, T.L. and DiMichele, W.A. 1992. Comparative ecology and life-history biology of arborescent lycopsids in Late Carboniferous swamps of Euramerica. Annals of the Missouri Botanical Garden, 79, pp. 560-588. http:// dx.doi.org/10.2307/2399753 
Platt, N.H. and Keller, B. 1992. Distal alluvial deposits in a foreland basin setting - the Lower Freshwater Molasse (Lower Miocene), Switzerland: sedimentology, architecture and palaeosols. Sedimentology, 39, pp. 545. http://dx.doi.org/10.1111/j.1365-3091.1992.tb02136.x

Plint, A.G. and van de Poll, H.W. 1982. Alluvial fan and piedmont sedimentation in the Tynemouth Creek Formation (Lower Pennsylvanian) of southern New Brunswick. Maritime Sediments and Atlantic Geology, 18, pp. 104-128.

Poliakov, A.N.B., Podladchnikov, Y.Y., Dawson, E.C., and Talbot, C.J. 1996. Salt diapirism with simultaneous brittle faulting and viscous flow. In Salt tectonics. Edited by G.I. Alsop, D. Blundell, and I. Davison, I. Geological Society, Special Publication 100, pp. 291-302.

Pye, K., Dickson, A.D., Schiavon, N., Coleman, M.L., and Cox, M. 1990. Formation of siderite-Mg-calcite-iron sulphide concretions in intertidal marsh and sandflat sediments, north Norfolk, England. Sedimentology, v. 37, pp. 325-343. http://dx.doi.org/10.1111/j.1365-3091.1990. tb00962.x

Retallack, G.J. 2001. Soils of the past. Blackwell, Ames, Iowa, 404 p. http://dx.doi.org/10.1002/9780470698716

Roberts, H.H., Wells, J.T., and Kahn, J.H. 1983. Alluvial valley and upper deltaic plain. Guidebook prepared for the AAPG Modern Delta Field Seminar. American Association of Stratigraphic Palynologists, Houston, 23 p.

Rowan, M.G. 1995. Structural styles and evolution of allochthonous salt, central Lousiana outer shelf and upper slope. In Salt tectonics: a global perspective. Edited by M.P.A. Jackson, D.G. Roberts, and S. Snelson. American Association of Petroleum Geologists, Memoir 65, pp. 199-118.

Royer, D.L. 1999. Depth to pedogenic carbonate horizons: a paleoprecipitation indicator? Geology, 27, pp. 1123-1126. http://dx.doi.org/10.1130/0091-7613(1999)027<1123:DT PCHA > 2.3.CO;2

Rust, B.R., Gibling, M.R., and Legun, A.S. 1984. Coal depositional in an anastomosing-fluvial system: the Pennsylvanian Cumberland Group south of Joggins, Nova Scotia, Canada. In Sedimentology of coal and coalbearing sequences. Edited by R.A. Rahmani and R.A. Flores. International Association of Sedimentologists, Special Publication 7, pp. 105-120.

Ryan, R.J. and Boehner, R.C. 1994. Geology of the Cumberland Basin, Cumberland, Colchester and Pictou counties, Nova Scotia: Halifax, Nova Scotia Department of Natural Resources, Memoir 10, 222 p.

Ryan, R.J., Boehner, R.C., and Deal, A. 1990a. Cumberland Basin geology map, Apple River and Cape Chignecto, Cumberland County. Nova Scotia Department of Mines and Energy, scale 1:50,000.

Ryan, R.J., Boehner, R.C., Deal, A., and Calder, J.H. 1990b. Cumberland Basin geology map, Amherst, Springhill and
Parrsboro, Cumberland County. Nova Scotia Department of Mines and Energy, scale 1:50,000.

Ryan, R.J., Boehner, R.C., and Calder, J.H. 1991. Lithostratigraphic revisions of the upper Carboniferous to lower Permian strata in the Cumberland Basin, Nova Scotia and the regional implications for the Maritimes Basin in Atlantic Canada. Bulletin of Canadian Petroleum Geology, 39, pp. 289-314.

Rygel, M.C. and Gibling, M.R. 2006. Natural geomorphic variability recorded in a high-accommodation setting: fluvial architecture of the Pennsylvanian Joggins Formation, Atlantic Canada. Journal of Sedimentary Research, 76, pp. 1230-1251. http://dx.doi.org/10.2110/ jsr.2006.100

Rygel, M.C. and Shipley, B.C. 2005. "Such a section as never was put together before": Logan, Dawson, Lyell, and midnineteenth-century measurements of the Pennsylvanian Joggins section of Nova Scotia. Atlantic Geology, 41, pp. 87-102.

Rygel, M.C., Gibling, M.R., and Calder, J.H. 2004. Vegetation-induced sedimentary structures from fossil forests in the Pennsylvanian Joggins Formation, Nova Scotia. Sedimentology, 51, pp. 531-552. http://dx.doi. org/10.1111/j.1365-3091.2004.00635.x

Rygel, M.C., Fielding, C.R., Frank, T.D., and Birgenheier, L.P. 2008. The magnitude of Late Paleozoic glacioeustatic fluctuations: a synthesis. Journal of Sedimentary Research, 78, pp. 500-511. http://dx.doi.org/10.2110/jsr.2008.058

Scott, H.D., Selim, H.M., and Ward, L.B. 2000. MLRA 131 southern Mississippi Valley alluvium. In Water and chemical transport of soils of the southeastern USA. Edited by H.D. Scott. Southern Association of Agricultural Experiment Station Directors, Southern Cooperative Series Bulletin 395. URL <http://soilphysics.okstate.edu/ S257/index.html>, September 2013.

Shaw, W.S. 1951a. The Cumberland Basin of deposition. Unpublished Ph.D. thesis, Massachusetts Institute of Technology, Cambridge, $170 \mathrm{p}$.

Shaw, W.S. 1951b. Preliminary map, Springhill, Cumberland, and Colchester Counties, Nova Scotia, Paper: Ottawa, Geological Survey of Canada, Paper 51-11.

Skelly, R.L., Bristow, C.S., and Ethridge, F.G. 2003. Architecture of channel-belt deposits in aggrading shallow sandbed braided river: the lower Niobrara River, northeast Nebraska. Sedimentary Geology, 158, pp. 249270. http://dx.doi.org/10.1016/S0037-0738(02)00313-5

Skilliter, D.M. 2001. Distal marine influence in the Forty Brine section, Joggins, Nova Scotia, Canada. Unpublished M.S. thesis, Boston College, Boston, 96 p.

Smith, D.G. and Putnam, P.E. 1980. Anastomosed river deposits - modern and ancient examples in Alberta, Canada. Canadian Journal of Earth Sciences, 17, pp. 1396-1406. http://dx.doi.org/10.1139/e80-147

Smith, M.G. 1991. The floodplain deposits and palaeosol 
profiles of the Late Carboniferous Cumberland Coal Basin, exposed at Joggins, Nova Scotia, Canada. Unpublished M.Sc. thesis, University of Guelph, Guelph, Ontario, Canada, $372 \mathrm{p}$.

Smith, N.D. and Pérez-Arlucea, M. 2004. Effects of peat on the shape of alluvial channels: examples from the Cumberland Marshes, Saskatchewan, Canada. Geomorphology, 61, pp. 323-335. http://dx.doi. org/10.1016/j.geomorph.2004.01.006

St. Peter, C.J. and Johnson, S.C. 2009. Stratigraphy and structural history of the late Paleozoic Maritimes Basin in southeastern New Brunswick, Canada. New Brunswick Department of Natural Resources; Minerals Policy and Planning Division, Memoir 3, 348 p.

Stevenson, F.J. 1969. Pedohumus: accumulation and diagenesis during the Quaternary. Soil Science, 197, pp. 470-479. http://dx.doi.org/10.1097/00010694196906000-00012

Stimson, M. and MacRae, R.A. 2010. Evidence of fossil horseshoe crabs from Joggins, Nova Scotia: paleoichnology and paleoenvironmental implications. Atlantic Geology, 46, p. 69.

Stimson, M., Lucas, S.G., and Melanson, G. 2012. The smallest known tetrapod footprints: Batrachichnus salamandroides from the Carboniferous of Joggins, Nova Scotia, Canada. Ichnos, 19, pp. 127-140. http://dx.doi.org /10.1080/10420940.2012.685206

Tandon, S.K. and Gibling, M.R. 1994. Calcrete and coal in Late Carboniferous cyclothems of Nova Scotia, Canada: climate and sea-level changes linked. Geology, 22, pp. 755-758. http://dx.doi.org/10.1130/00917613(1994)022<0755:CACILC>2.3.CO;2

Tibert, N.E. and Dewey, C.P. 2006. Velatomorpha, a new healdioidean ostracode genus from the early Pennsylvanian Joggins Formation, Nova Scotia, Canada. Micropaleontology, 52, pp. 51-66. http://dx.doi. org/10.2113/gsmicropal.52.1.51

Törnqvist, T.E., van Ree, M.H.M., and Faessen, E.L.J.H. 1993. Longitudinal facies architectural changes of a Middle Holocene anastomosing distributary system (Rhine-Meuse Delta, central Netherlands). Sedimentary Geology, 85, pp. 203-219. http://dx.doi.org/10.1016/00370738(93)90084-I

Utting, J. and Wagner, R.H. 2005. Megaflora of the Upper Carboniferous Cumberland Group, Joggins area, Nova Scotia and New Brunswick, GAC-MAC-CSPG-CSSS Joint Meeting: Abstracts: Halifax, Nova Scotia, pp. 197.

Utting, J., Giles, P.S., and Dolby, G. 2010. Palynostratigraphy of Mississippian and Pennsylvanian rocks, Joggins area, Nova Scotia and New Brunswick, Canada. Palynology, 34, pp. 43-89. http://dx.doi.org/10.1080/01916121003620569

Vasey, G.M. 1984. Westphalian microfaunas in Nova Scotia: palaeoecology and correlation. Unpublished Ph.D. thesis, University of Strathclyde, Glasgow, 395 p.
Waldron, J.W.F. and Rygel, M.C. 2005. Role of evaporite withdrawal in the preservation of a unique coalbearing succession: Pennsylvanian Joggins Formation, Nova Scotia. Geology, 33, pp. 337-340. http://dx.doi. org/10.1130/G21302.1

Waldron, J.W.F., Roselli, C., and Johnston, S.K. 2007. Transpressional structures on a Late Paleozoic intracontinental transform fault, Canadian Appalachians. In Tectonics of strike-slip restraining and releasing bends. Edited by W.D. Cunningham and P. Mann. Geological Society, Special Publication 290, pp. 367-385.

Waldron, J.W.F., Rygel, M.C., Gibling, M.R., and Calder, J.H. 2013. Evaporite tectonics and the late Paleozoic stratigraphic development of the Cumberland basin, Appalachians of Atlantic Canada. Geological Society of America Bulletin, 125, pp. 945-960. http://dx.doi. org/10.1130/B30718.1

Way, J.H. 1968. Bed thickness analysis of some Carboniferous fluvial sedimentary rocks near Joggins, Nova Scotia. Journal of Sedimentary Petrology, 38, pp. 424-433. http://dx.doi.org/10.1306/74D719B0-2B21-11D78648000102C1865D

Webb, G.W. 1963. Occurrence and exploration significance of strike slip faults in southern New Brunswick, Canada. American Association of Petroleum Geologist Bulletin, 47, pp. 1904-1927.

Editorial responsibility: Robert A. Fensome

\section{APPENDIX 1}

Information required by the North American Stratigraphic Code for revision of the Joggins Formation and the changing of the position of the Joggins-Springhill Mines contact.

\section{Historical Background, Intent, and Utility}

Bell (1914) introduced the Joggins Formation as a name for much of the coal-bearing, mudrock-dominated stratal succession in the western Cumberland Basin. This name was abandoned (Bell 1943; Shaw 1951b; Copeland 1959; Belt 1964; Kelley 1967) and later reintroduced by Ryan et al. (1991) to include coal-bearing strata in Logan's Divisions 4 and 5 . The definition was further revised by Calder et al. (2005) and Davies et al. (2005) who restricted it to a 915.5-m-thick interval that contained coal, organic-rich limestones, sandstones and variably colored mudrock and excluded the non-coal-bearing strata in Logan's Division 5. Their definition matched Logan's (1845) Division 4; the lower boundary occurred at the base of the lowermost coal and the upper boundary was at the top of the uppermost limestone. 
We modify Davies et al.'s (2005) definition by placing the boundary with the overlying Springhill Mines Formation atop the uppermost package of interbedded organic-rich limestone, laminated dark mudrock, and sharp-based sandstone assignable to Davies et al.'s (2005) "open water facies association." This mappable, lithostratigraphic definition places all strata deposited as a direct consequence of the widespread flooding events that inundated the basin with brackish waters within the Joggins Formation. The category, name, and rank of this lithostratigraphic unit remain unchanged.

\section{Type Section and Boundaries}

The type section of the Joggins Formation crops out along the southern shore of Chignecto Bay near the community of Joggins in Cumberland County, Nova Scotia (Calder et al. 2005; Davies et al. 2005). The lower boundary remains unchanged and occurs approximately $500 \mathrm{~m}$ south of the mouth of Little River, at the base of the lowest coal within the mudrock-dominated portion of the Cumberland Group (at approximately $45.713748^{\circ} \mathrm{N}, 64.434603^{\circ} \mathrm{W}$ ). As shown in the accompanying detailed measured section, the upper boundary is placed atop a sheet sandstone 16.9 $\mathrm{m}$ upsection from the old boundary (at approximately $45.690397^{\circ} \mathrm{N}, 64.451663^{\circ} \mathrm{W}$ ). This modification makes the Joggins Formation $932.4 \mathrm{~m}$ thick at the type section; detailed sedimentological logs are provided in Davies et al. (2005) and in Appendix 3 of this manuscript. Both upper and lower boundaries are conformable.

\section{Unit Description}

At its type section, the Joggins Formation is a 932.4-m-thick unit that contains coal, sheet sandstones, channel-body sandstones, red, green, and grey mudrocks, organic-rich limestones and laminated dark shales. Davies et al. (2005) considered these lithologies in terms of the open water, poorly drained, and well drained facies associations and used them to recognize numerous cycles caused by flooding and subsequent infilling. Unlike the underlying Little River Formation, the Joggins Formation contains coal, limestone, and relatively thick occurrences of green and grey mudrock. The overlying Springhill Mines Formation is coalbearing and contains a lower percentage of red mudrock; unlike the Joggins Formation, it lacks the limestones, sharpbased sandstones, and dark laminated mudrocks assignable to Davies et al.'s (2005) open water facies association.

\section{Distribution and Correlation}

The distribution and correlation of this unit is identical to the comprehensive account provided by Calder et al. (2005), Davies et al. (2005), and as described above. The Joggins Formation thins inland; within the Athol Syncline it overlies the Little River Formation and to the southeast becomes interbedded with, and partially overlies, the basin margin conglomerates of the Polly Brook Formation (Ryan et al. 1991; Calder et al. 2005).

In the coastal exposure described in this paper, the Joggins Formation is conformably overlain by the MacCarrons River Member of the Springhill Mines Formation. Although the limit of open-water deposition is uncertain, the high percentage of transported progymnosperms and gymnosperms within OWFA deposits suggests that much of the basin floor was flooded (Falcon-Lang 2003; 2005; Davies et al. 2005). Consequently, we show the Joggins Formation as being conformably overlain by the Springhill Mines Formation throughout the Cumberland Basin (Calder 1995; Davies et al. 2005).

\section{Age}

As described above, Utting et al. (2010) assigned the Joggins Formation to the Raistrickia fulva spore zone (Langsettian); more detailed dates are not possible given the lack of biostratigraphically useful fossils.

\section{APPENDIX 2}

Information required by the North American Stratigraphic Code to define the MacCarrons River Member of the Springhill Mines Formation.

\section{Historical Background, Intent, and Utility}

The Springhill Mines Formation was originally proposed by Calder (1991), and formally introduced by Ryan et al. (1991) to include the predominantly grey, coal-bearing part of the Cumberland Group within the Cumberland Basin that lacked organic-rich limestones. They defined a composite type section from the Springhill area comprising a series of drill cores with a reference section along the coast. The reference section of the Springhill Mines Formation had a lower contact at the base of a sandstone 168 feet, 2 inches $(\sim 51.3 \mathrm{~m})$ above the base of Division 3 (the top of the uppermost limestone in the section). The upper contact was not specified, but appears on their diagrams as corresponding to the top of a dark mudrock that caps Logan's Division 3. Members were informally introduced by Calder (1991), and the MacCarrons River member was depicted on some of the diagrams in Ryan et al. (1991) but not formally described.

Calder (1995) recognized two informal members in the Springhill Mines Formation in his geology map of the Springhill coalfield. The Coal Mine Brook member, embodying the historically economic coal beds of the formation, comprises the lower $500 \mathrm{~m}$ of strata in the type area near Springhill. It contains grey mudrock with siderite, 
thick $(<5 \mathrm{~m})$ humic coal, multistorey sandstones, and thin, discontinuous cone-in-cone limestones. The overlying, 200-m-thick MacCarrons River member contains sandstone and coal as well as red and mottled mudrock with siderite nodules. The MacCarrons River member becomes dominant away from the Cobequid Highlands and comprises the entirety of the coastal exposure of the Springhill Mines Formation.

Davies et al. (2005) favored the boundary proposed by Logan (1845) and moved the contact between the Joggins and Springhill Mines formations to the top of the uppermost limestone in Division 3 (915.5 $\mathrm{m}$ in their section). In this paper, we move the contact $16.9 \mathrm{~m}$ upsection to the top of the uppermost package of interbedded organic-rich limestone, dark laminated mudrock, and sharp-based sandstones assignable to Davies et al.'s (2005) open water facies association. The category, name, and rank of this lithostratigraphic unit remain unchanged.

We formally define the redbed-dominated MacCarrons River Member of the Springhill Mines Formation as the coal-bearing part of the Cumberland Group characterized by thin coal beds, red and grey mudrocks and by the absence of successions of interbedded organic-rich limestone, dark laminated mudrocks, and sharp-based sandstones assignable to Davies et al.'s (2005) open water facies association.

\section{Type Section and Boundaries}

The type section of the MacCarrons River Member of the Springhill Mines Formation crops out along the southern shore of Chignecto Bay, to the south of the town of Joggins in Cumberland County, Nova Scotia. The MacCarrons River Member comprises the entirety of the 697-m-thick coastal exposure of the Springhill Mines Formation. The contact with the underlying Joggins Formation is placed atop a sheet sandstone $16.9 \mathrm{~m}$ upsection from the old boundary (at approximately $45.69040^{\circ} \mathrm{N}, 64.45166^{\circ} \mathrm{W}$ ). This modification renders the Joggins Formation $932.4 \mathrm{~m}$ thick at the type section; detailed measured sections are provided in Davies et al. (2005) and in Appendix 3 of this manuscript.

The contact with the overlying Ragged Reef Formation occurs at the base of a large multistorey sandstone that contains the lowest extraformational gravel (quartz granules to $4 \mathrm{~mm}$ ) above the coal-bearing part of the Cumberland Group (at approximately $45.67463^{\circ} \mathrm{N}, 64.48234^{\circ} \mathrm{W}$ ). The base of this channel sits atop a gleyed interval that likely corresponds to the 2-foot-thick (0.61-m-thick) carbonaceous shale at the top of Logan's (1845) Division 3. Both upper and lower boundaries are conformable.

\section{Unit Description}

The type section of the MacCarrons River Member of the Springhill Mines Formation is $697 \mathrm{~m}$ thick and contains strata that can be assigned to poorly drained and well drained facies associations. Strata of the poorly drained facies association include green and grey mudrocks, thin coals $(<18 \mathrm{~cm}$ thick), sheet sandstones, and channel bodies. Strata of the well drained facies association comprise reddish-brown mudrocks, sheet sandstones, and channel bodies. Strata reflecting poorly drained conditions are thick and abundant in the lower half of the formation and welldrained intervals become thick and more abundant in the upper half. A similar trend is seen at Springhill, where 164 $\mathrm{m}$ of red and grey siderite-bearing mudrocks with coal beds (informally assigned by Calder, 1991, to the MacCarrons River member) are succeeded by predominantly red mudrocks and grey sandstones (informally assigned to the Harrison Brook member of the Ragged Reef Formation by Calder, 1991).

\section{Distribution and Correlation}

Near Springhill, the MacCarrons River Member overlies, and partially intertongues with, the predominantly grey, thick coal-bearing strata of the Coal Mine Brook member of the Springhill Mines Formation (Calder 1995). The underlying, well developed grey coal-bearing strata of the Coal Mine Brook member thin toward the coast so that in the Joggins section, the MacCarrons River Member conformably overlies the limestone and coal-bearing strata of the Joggins Formation. The depositional limit of OWFA deposits in the Joggins Formation is uncertain, but the abundance of transported progymnosperms and gymnosperms within these deposits suggests that much of the basin floor was flooded (Falcon-Lang 2003; 2005; Davies et al. 2005) and that the Springhill Mines Formation conformably overlies the Joggins Formation throughout the Cumberland Basin (Calder 1995; Davies et al. 2005).

Near Springhill, the MacCarrons River Member overlies, and partially intertongues with, the predominantly grey, thick coal-bearing strata of the Coal Mine Brook member of the Springhill Mines Formation (Calder 1995). The underlying, well developed grey coal-bearing strata of the Coal Mine Brook member thin toward the coast so that in the Joggins section, the MacCarrons River Member conformably overlies the limestone and coal-bearing strata of the Joggins Formation. The depositional limit of OWFA deposits in the Joggins Formation is uncertain, but the abundance of transported progymnosperms and gymnosperms within these deposits suggests that much of the basin floor was flooded (Falcon-Lang 2003; 2005; Davies et al. 2005) and that the Springhill Mines Formation conformably overlies the Joggins Formation throughout the Cumberland Basin (Calder 1995; Davies et al. 2005).

The MacCarrons River Member has an interbedded to intertonguing relationship with the overlying Ragged Reef Formation near Springhill (Calder 1995). Although this 
boundary is placed at the base of the lowest conglomeratic channel body in the coastal section, a locally intertonguing relationship is likely across much of the rest of the Cumberland Basin as well (Ryan et al. 1990a).

\section{Age}

On the basis of palynology, Dolby (1991) assigned the strata of the MacCarrons River Member at the coast an earliest Westphalian B (Duckmantian) age. As described above, Utting et al. (2010) assigned these same strata to their Raistrickia fulva spore zone, which they interpreted to be Langsettian. The absence of marine index fossils and the possible ecological exclusion of index palynomorphs contributes to the disparate biostratigraphic interpretations.

\section{APPENDIX 3}

Measured section of the Springhill Mines Formation exposed in the Joggins Fossil Cliffs UNESCO World Heritage Site. Meterage in this measured section is designated on the 10:000 map provided in Figure 2. 


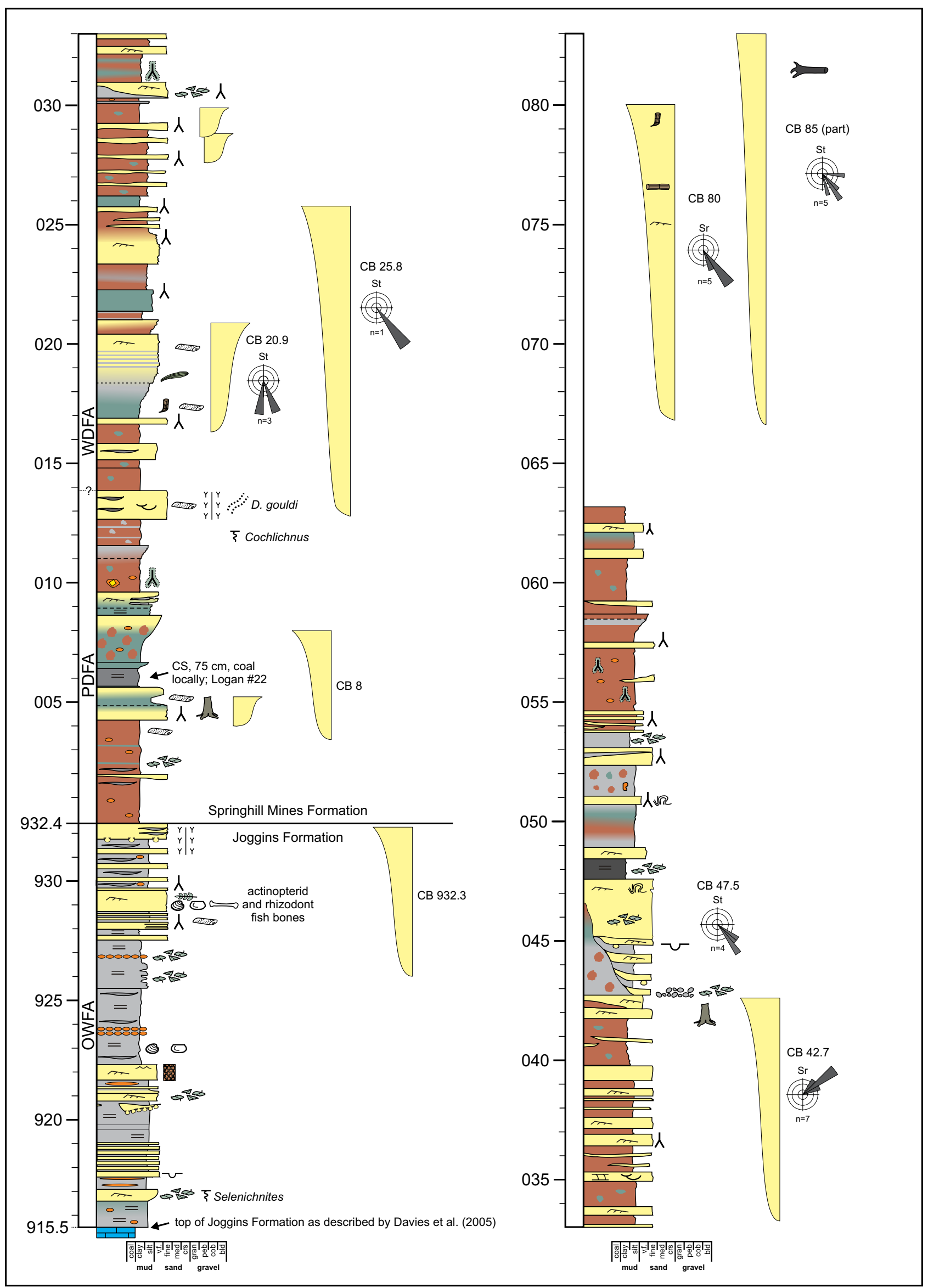




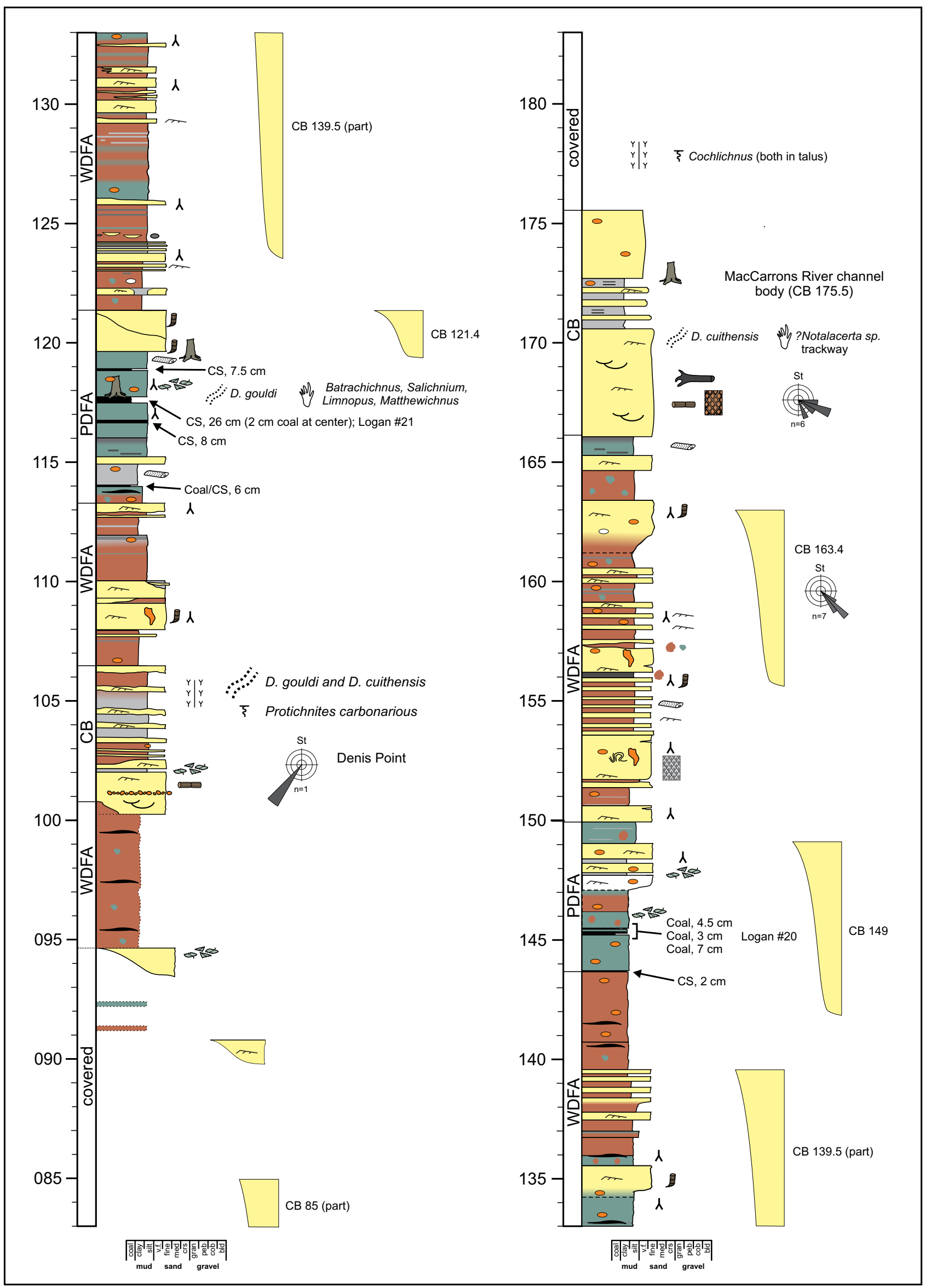




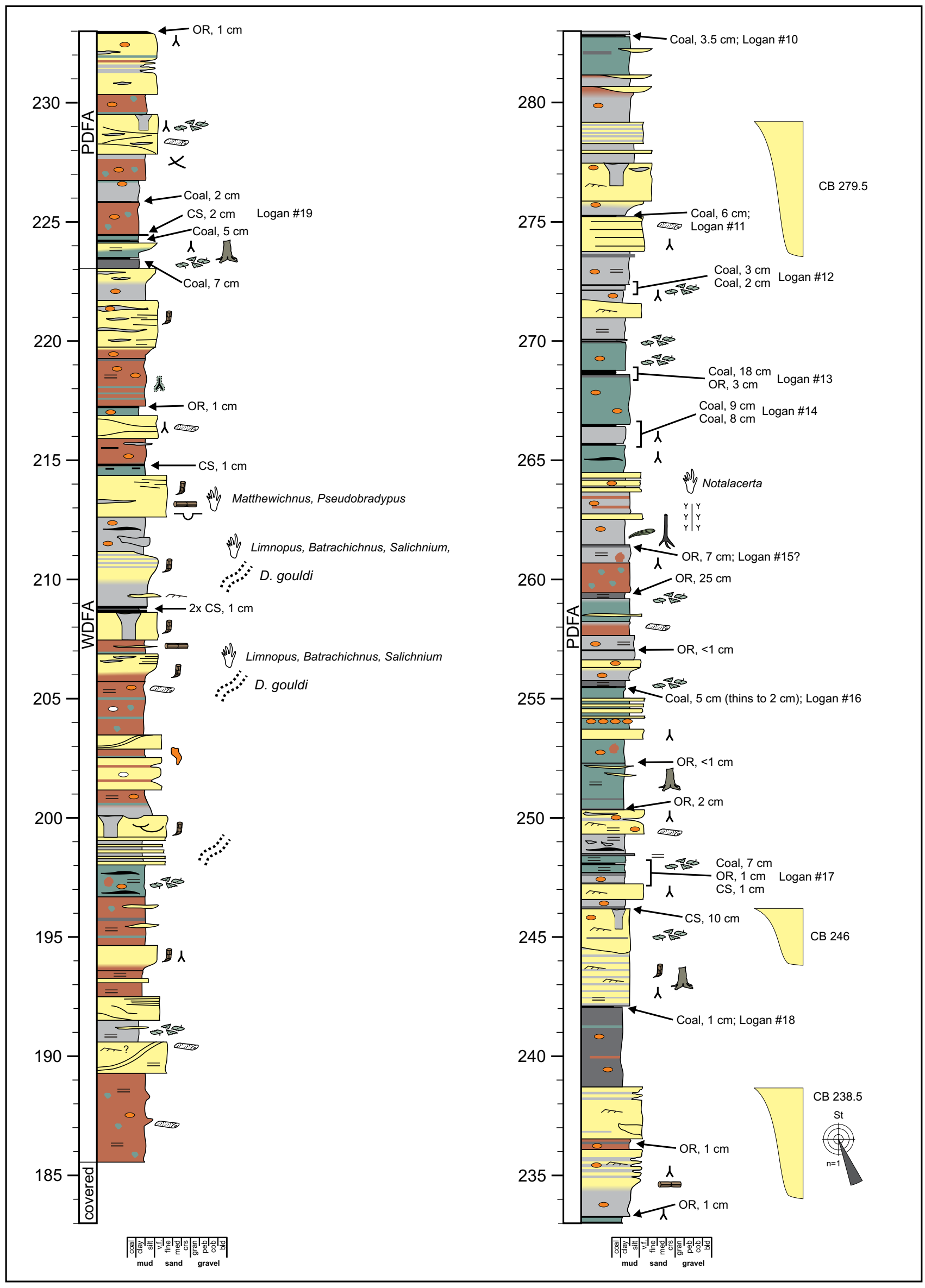




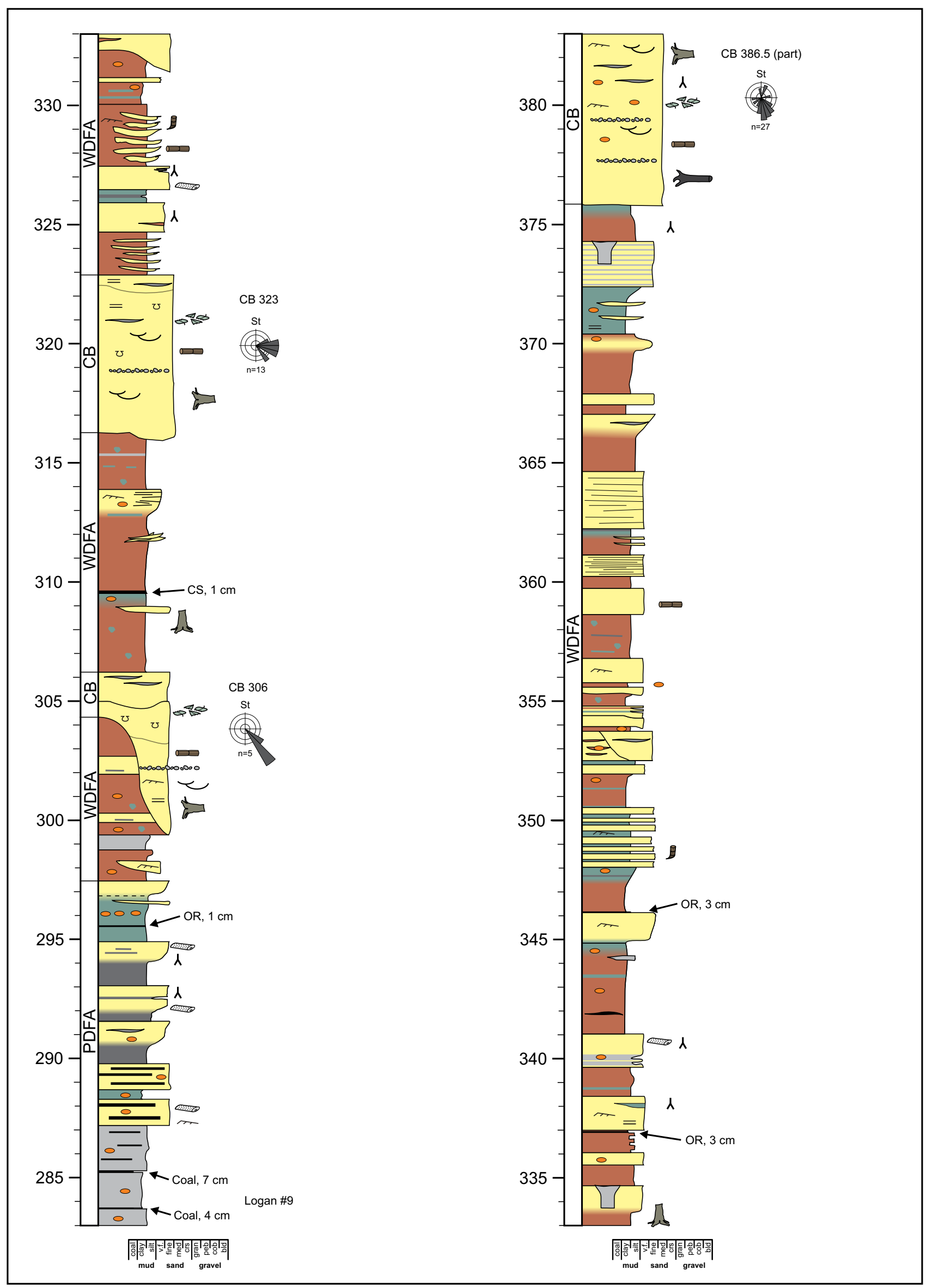




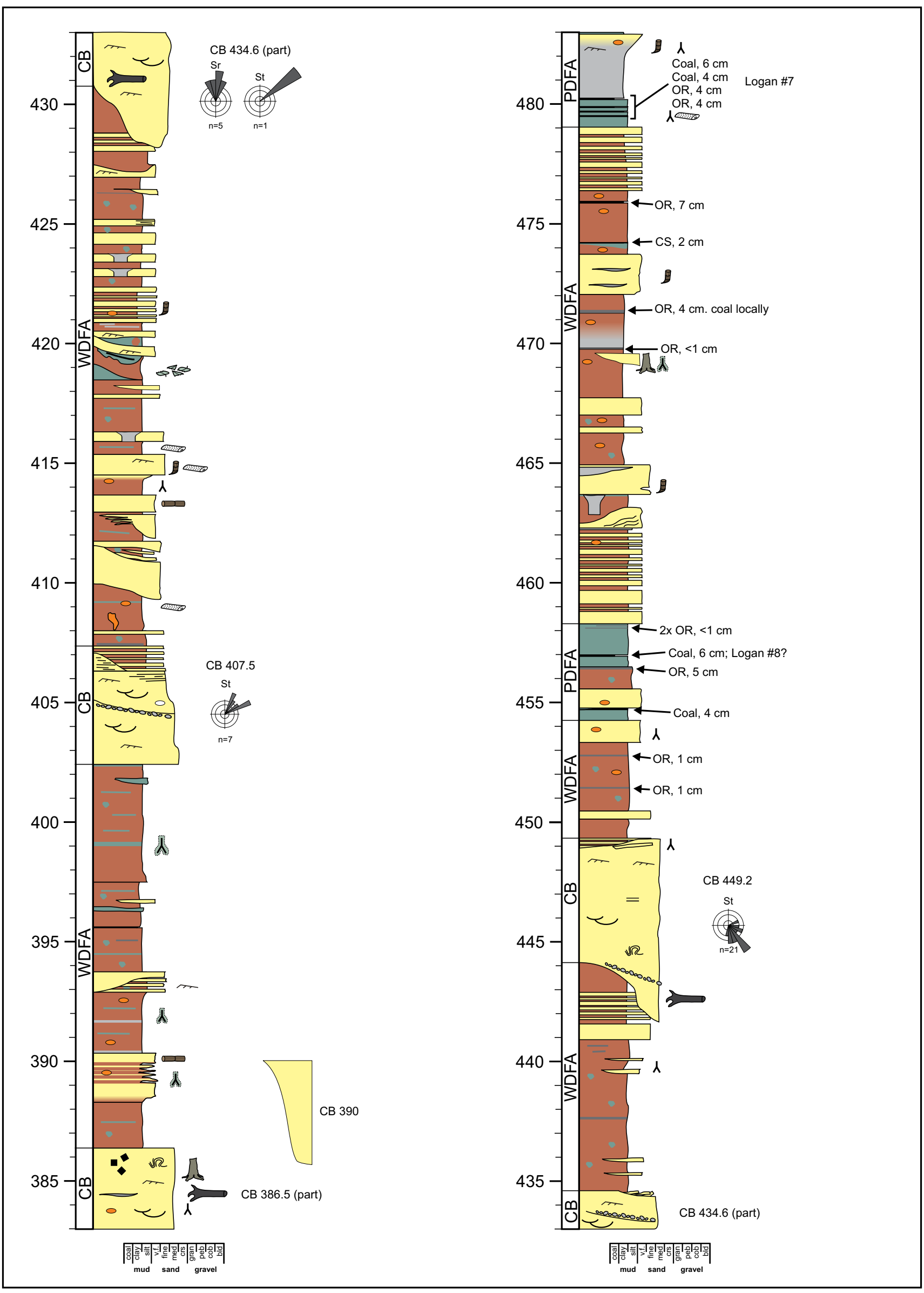




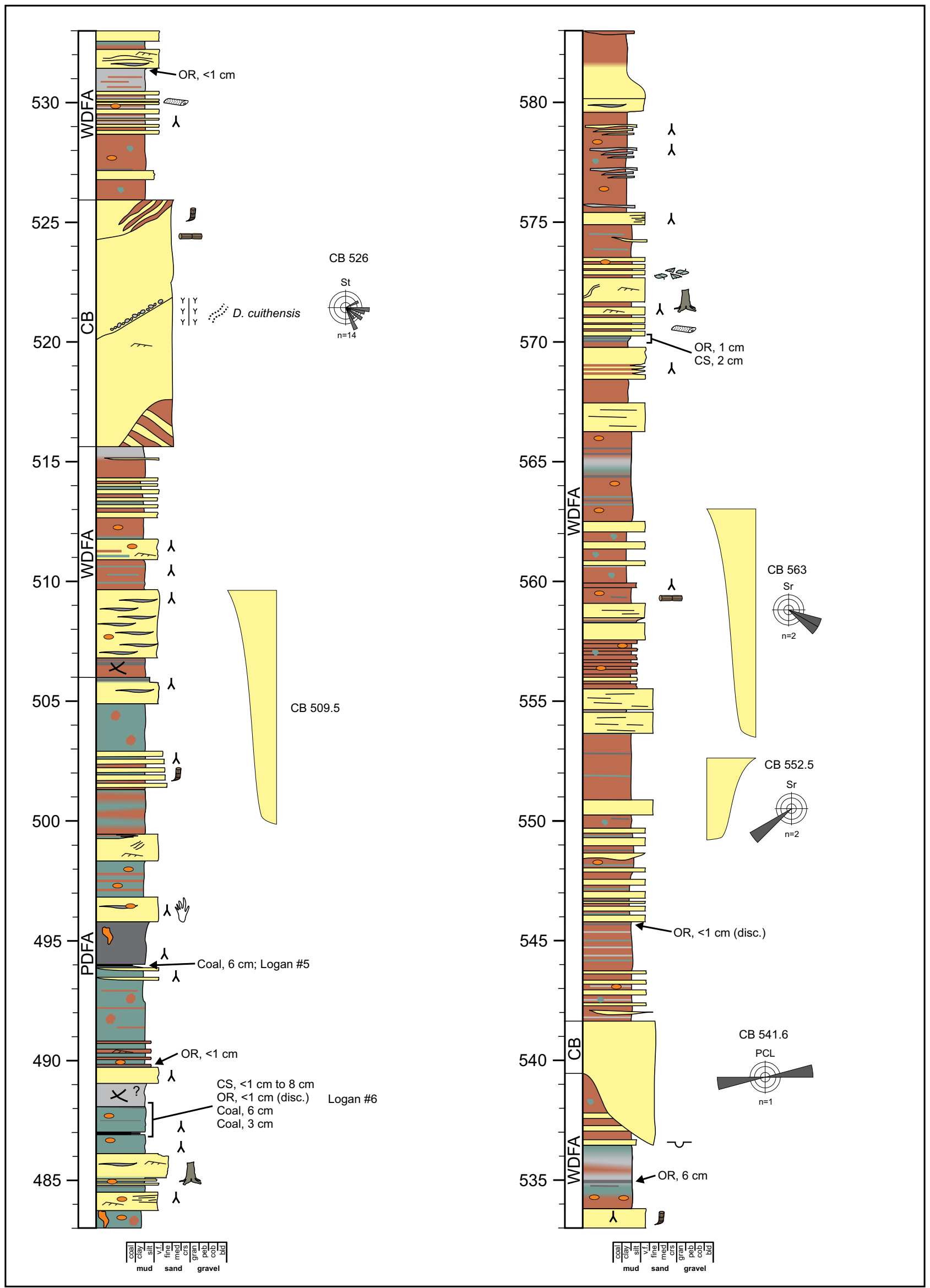




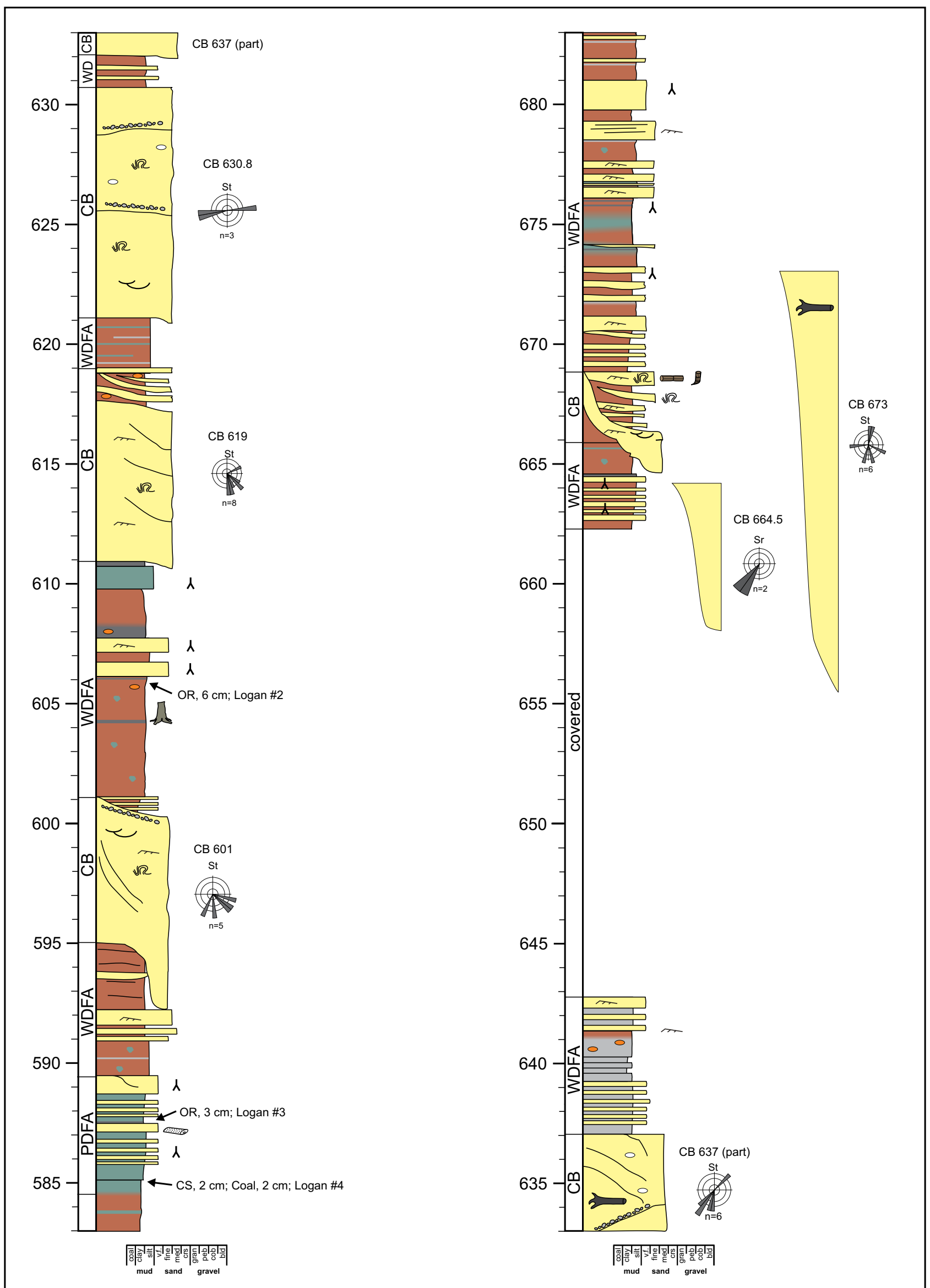




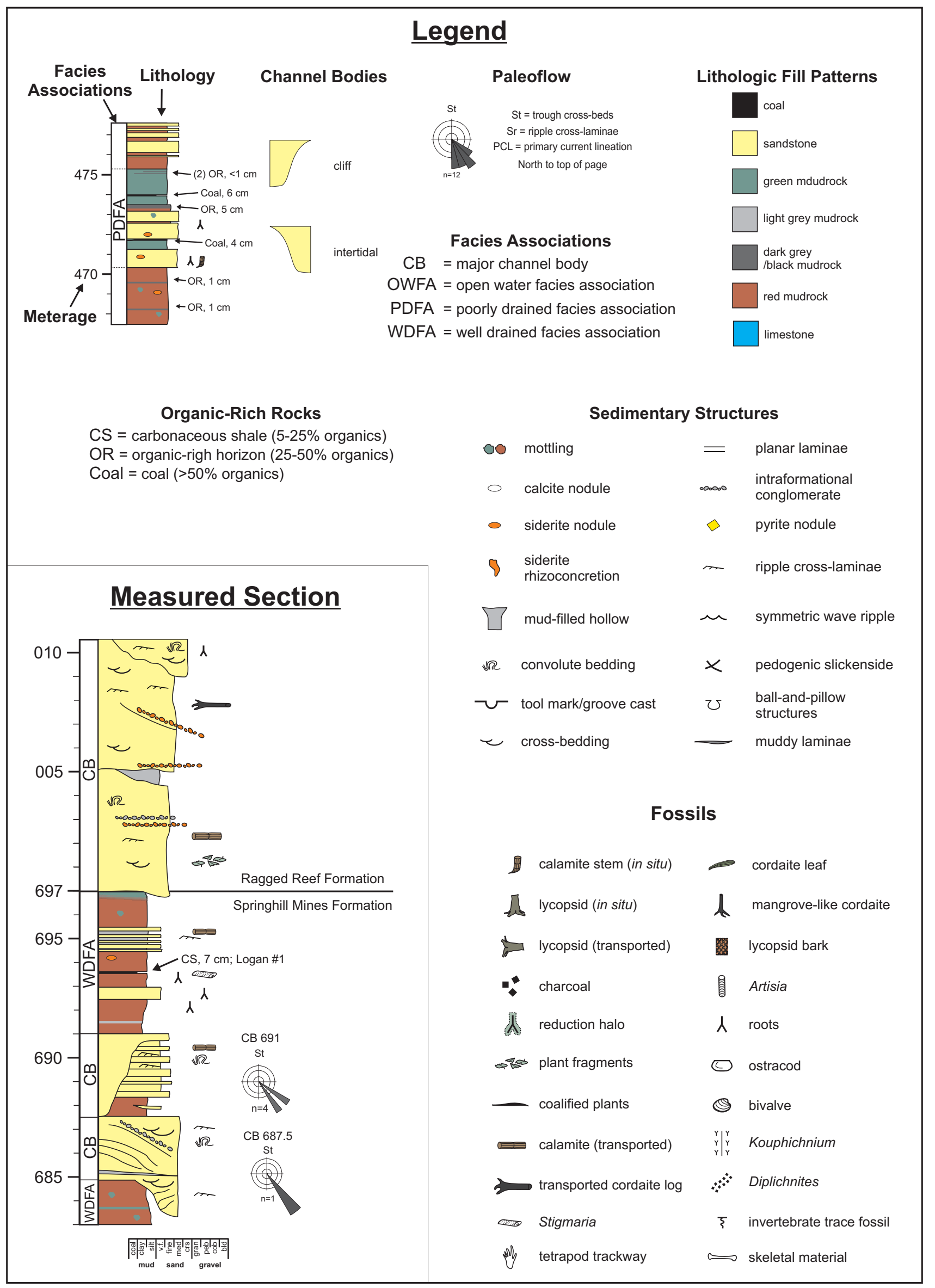

